\title{
Process analysis of shea butter solvent fractionation using a generic systematic approach
}

Perederic, Olivia A.; Mansouri, Seyed Soheil; Appel, Sten ; Sarup, Bent; Gani, Rafiqul; Woodley, John M.; Kontogeorgis, Georgios

Published in:

Industrial \& Engineering Chemistry Research

Link to article, DOI:

10.1021/acs.iecr.9b06719

Publication date:

2020

Document Version

Peer reviewed version

Link back to DTU Orbit

Citation (APA):

Perederic, O. A., Mansouri, S. S., Appel, S., Sarup, B., Gani, R., Woodley, J. M., \& Kontogeorgis, G. (2020). Process analysis of shea butter solvent fractionation using a generic systematic approach. Industrial \& Engineering Chemistry Research, 59(19), 9152-9164. https://doi.org/10.1021/acs.iecr.9b06719

\section{General rights}

Copyright and moral rights for the publications made accessible in the public portal are retained by the authors and/or other copyright owners and it is a condition of accessing publications that users recognise and abide by the legal requirements associated with these rights.

- Users may download and print one copy of any publication from the public portal for the purpose of private study or research.

- You may not further distribute the material or use it for any profit-making activity or commercial gain

- You may freely distribute the URL identifying the publication in the public portal 


\title{
Process Systems Engineering
}

\author{
Process analysis of shea butter solvent \\ fractionation using a generic systematic approach \\ Olivia Perederic, Seyed Soheil Mansouri, Sten Appel, Bent Sarup, \\ Rafiqul Gani, John M. Woodley, and Georgios M. Kontogeorgis
}

Ind. Eng. Chem. Res., Just Accepted Manuscript • DOI: 10.1021/acs.iecr.9b06719 • Publication Date (Web): 18 Apr 2020

Downloaded from pubs.acs.org on April 19, 2020

\section{Just Accepted}

"Just Accepted" manuscripts have been peer-reviewed and accepted for publication. They are posted online prior to technical editing, formatting for publication and author proofing. The American Chemical Society provides "Just Accepted" as a service to the research community to expedite the dissemination of scientific material as soon as possible after acceptance. "Just Accepted" manuscripts appear in full in PDF format accompanied by an HTML abstract. "Just Accepted" manuscripts have been fully peer reviewed, but should not be considered the official version of record. They are citable by the Digital Object Identifier (DOI@). "Just Accepted" is an optional service offered to authors. Therefore, the "Just Accepted" Web site may not include all articles that will be published in the journal. After a manuscript is technically edited and formatted, it will be removed from the "Just Accepted" Web site and published as an ASAP article. Note that technical editing may introduce minor changes to the manuscript text and/or graphics which could affect content, and all legal disclaimers and ethical guidelines that apply to the journal pertain. ACS cannot be held responsible for errors or consequences arising from the use of information contained in these "Just Accepted" manuscripts. 


\title{
Process analysis of shea butter solvent fractionation using a generic systematic approach
}

\author{
Olivia A. Perederic, ${ }^{*} \dagger$ Seyed Soheil Mansouri, ${ }^{\dagger}$ Sten Appel, $\ddagger$ Bent Sarup, $\ddagger$ Rafiqul Gani, $\uparrow, \S, \|$ \\ John M. Woodley, ${ }^{\dagger}$ Georgios M. Kontogeorgis ${ }^{\dagger}$ \\ $\dagger$ Department of Chemical and Biochemical Engineering, Technical University of Denmark, \\ DK-2800 Kgs. Lyngby, Denmark \\ † Edible Oil Systems Business Unit, Alfa Laval Copenhagen A/S, Maskinvej 5, DK-2860 \\ Søborg, Denmark \\ $\S$ PSE for SPEED, Skyttemosen 6, DK-3450 Allerød, Denmark \\ || College of Control Science and Engineering, Zhejiang University, Hangzhou, China \\ oper@kt.dtu.dk
}

\begin{abstract}
The application of lipid feedstocks has expanded across different industries as a result of bio-based economies development, consumers and societal requirements. The need for new and better performing lipid-based processes and products has resulted in extensive research within lipid thermodynamic property modelling. In this work, property models for lipid pure compounds and
\end{abstract}


mixtures are validated by applying them to an industrial process: shea butter solvent fractionation with acetone. The process modelling, simulation and analysis are performed through a systematic approach consisting of four steps: (1) process data collection, (2) process modelling, design and simulation, (3) process performance analysis, (4) process hot-spots identification and retrofit solutions. The Lipids Database, that includes the required models for pure compounds and mixtures, is used to perform the modelling and simulation. The analysis of the results shows energy savings potential, which is achieved through process heat integration and retrofit of separation units.

\section{INTRODUCTION}

In the context of population growth and climate change, there is a great need to increase the valorisation of bio-resources in all areas of industrial applications (e.g. food, fuels, etc.). To maintain competitiveness under current market conditions, $R \& D$ initiatives for new feedstock resources, new products and improved processes have been adopted by the industry in recent years. The continuous expansion of the lipid market is a result of increasing utilisation of these types of feedstocks for the production of food (e.g. specialty fats and oils used in confectionery products), pharmaceutical products (e.g. vitamin E and other supplements), cosmetics, oleochemicals (e.g. fatty acids, fatty ester), fuels, and many others. ${ }^{1,2}$ The advances within the lipid processing industry can be achieved through well-established process systems engineering (PSE) methods and tools, which currently are not extensively applied within this industry. Although oil extraction ${ }^{3}$, oil refining ${ }^{4,5}$ and biodiesel production ${ }^{6-8}$ processes, have been rigorously modelled and simulated, for many other lipid-based processes, including fractionation, a similar detailed investigation has not yet been performed. 
All PSE methods and tools to be employed for process development requires good knowledge and understanding of the properties of involved chemicals and their mixtures. Thus, understanding of thermo-physical properties and phase equilibria of lipid compounds becomes crucial in the given context. A detailed description of the role that properties may play has been highlighted by Gani and $\mathrm{O}^{\prime}$ Connell ${ }^{9}$. It is even more important that if new products and processes emerge based on new lipid feedstocks, models for estimating the properties for the new mixtures, as well as new lipid compounds, for which no experimental data is available yet, are needed. That is, the predictive capabilities of the property models need to be verified first. New advances within lipid phase equilibria modelling have resulted in the availability of new sets of parameters for group contribution predictive models like UNIFAC (i.e. Original, ${ }^{2}$ Linear, Lyngby Modified and Dortmund Modified ${ }^{10}$ ) allowing the estimation of properties for a wide range of mixtures for this class of compounds. The currently available thermodynamic models for pure compounds ${ }^{4,11,12}$ and mixtures $^{2,10}$ are included in the Lipids Database, that can be used within different PSE domains ${ }^{2}$.

The current work aims to apply the lipid-based thermodynamic property models covered in the Lipids Database along with different model-based computer-aided methods and tools for development and analysis of a lipid process of industrial importance. The methodology used is systematic and generic while it's the application is highlighted to investigate in detail the fractionation of shea butter using acetone as a solvent. The work, performed in close collaboration with Alfa Laval, lead to significant energy savings for solvent recovery reflected very well in the process operational costs savings analysis. The identified solutions tackle the main drawbacks of the solvent fractionation process: high energy consumption and high operational costs.

\section{Lipid fractionation process overview}


Shea butter is one of the five alternative fat sources accepted in chocolate production as per EU Commission's Directive 2000/36/EC. The two products obtained from the fractionation of shea butter are shea stearin and shea olein. The particular properties of shea stearin are due to the presence of high amounts of symmetrical stearic-rich triacylglycerols like 1,3-distearo-2-olein present in shea butter. Shea stearin is used as a cocoa butter equivalent (CBE) in chocolate products to enhance the fat profile and stability, to reduce fat blooming and migration, to ensure softness, gloss and snap properties, which expand the shelf life and improve the quality of the final product. ${ }^{13}$ Shea olein has an extensive application in cosmetic formulations, confectionery and speciality fat products ${ }^{14}$.

In the lipid processing industry, fractionation refers to the crystallization-based separation, which can be performed in one or more steps. The process is used to tailor the chemical composition of the resulting fractions needed for specific applications under controlled temperature conditions. ${ }^{15}$ The main technologies used for fractionation at an industrial scale are dry fractionation, solvent fractionation and detergent fractionation. Dry fractionation, also known as simple crystallisation or crystallisation from the melt, is performed by separating the product directly from the liquid fat mixture by cooling down without adding any other compounds to facilitate the process and then separate the crystal by centrifugation or filtration. The detergent fractionation process performs the crystallization from the melt, the same as dry fractionation. To separate the crystals, an aqueous solution containing a surfactant is used to solubilize the crystals in the aqueous phase and then separate them by centrifugation. The cost of effluent disposal, legislative restrictions in certain countries and important advances in dry and solvent fractionation performance lead to the decline of detergent fractionation process. ${ }^{16}$ The solvent fractionation process consists of performing the crystallization in the presence of a solvent, followed by filtration 
of the crystals to which a washing step can be added. The solvent fractionation is used when the desired fractions need a sharp separation from a mixture containing compounds with very close melting points and dry fractionation does not achieve the required separation. The main solvents used are acetone and hexane, but other solvents, such as alcohol, ketones, or azeotropic mixtures are reported in the literature as well. ${ }^{16}$ The solvent selection is dependent mainly on the oil composition (e.g. presence of polar species such as free fatty acids and diacylglycerols) and less on the separation task (e.g. one triglyceride from another triglyceride). ${ }^{17}$ Though, there are studies showing acetone has a better performance in separating P-O-P (1,3-dipalmito-2-olein) from P-PO (1,2-dipalmito-3-olein) triglycerides, where P-O-P exhibit higher solubility than P-P-O. ${ }^{18}$ The solvent fractionation has the following advantages: faster crystallization, higher selectivity, more material that can be crystallized in one step, and higher separation efficiency of the crystals from the mother liquor. Current drawbacks of solvent fractionation are (1) extra safety precautions required due to the flammability of used solvents, (2) process energy requirements in terms of utility consumption for cooling and heating during crystallization and solvent recovery operation, (3) solvent loss. ${ }^{16}$ All these have resulted in employing solvent fractionation only for high-value products, which can assimilate the extra costs. ${ }^{19}$ The shea butter composition, as well as final product specifications (i.e. sharp melting point of shea stearin), requires the fractionation to be performed only by using a solvent.

The shea butter solvent fractionation process consists of three parts: (1) crystallization and separation of the products, (2) solvent recovery, and (3) solvent cooling, as presented in the simplified PFD (process flow diagram) in Figure 1. The first part of the process covers the crystallization and the combined filtration and washing operations. The crystallization takes place in a stirred vessel, while the filtration and washing are done with a horizontal belt filter operated 
under vacuum. The solvent is recovered through a series of flash units and steam stripping columns for both products. The objective of the steam stripping columns is to remove solvent traces in the final products thereby ensuring that the required specifications are achieved. The recovered solvent is cooled before being recycled back to the process. The low temperatures at which the crystallization is performed requires the cooling of the solvent with ammonia, in a refrigeration cycle.

The paper introduces aspects of process modelling, design and analysis using lipid-based thermodynamic models and appropriate computer-aided methods and tools for shea butter acetone fractionation. At the process level, the objective is to reduce the high energy demands, which is one of the main drawbacks of the solvent-based fractionation processes.

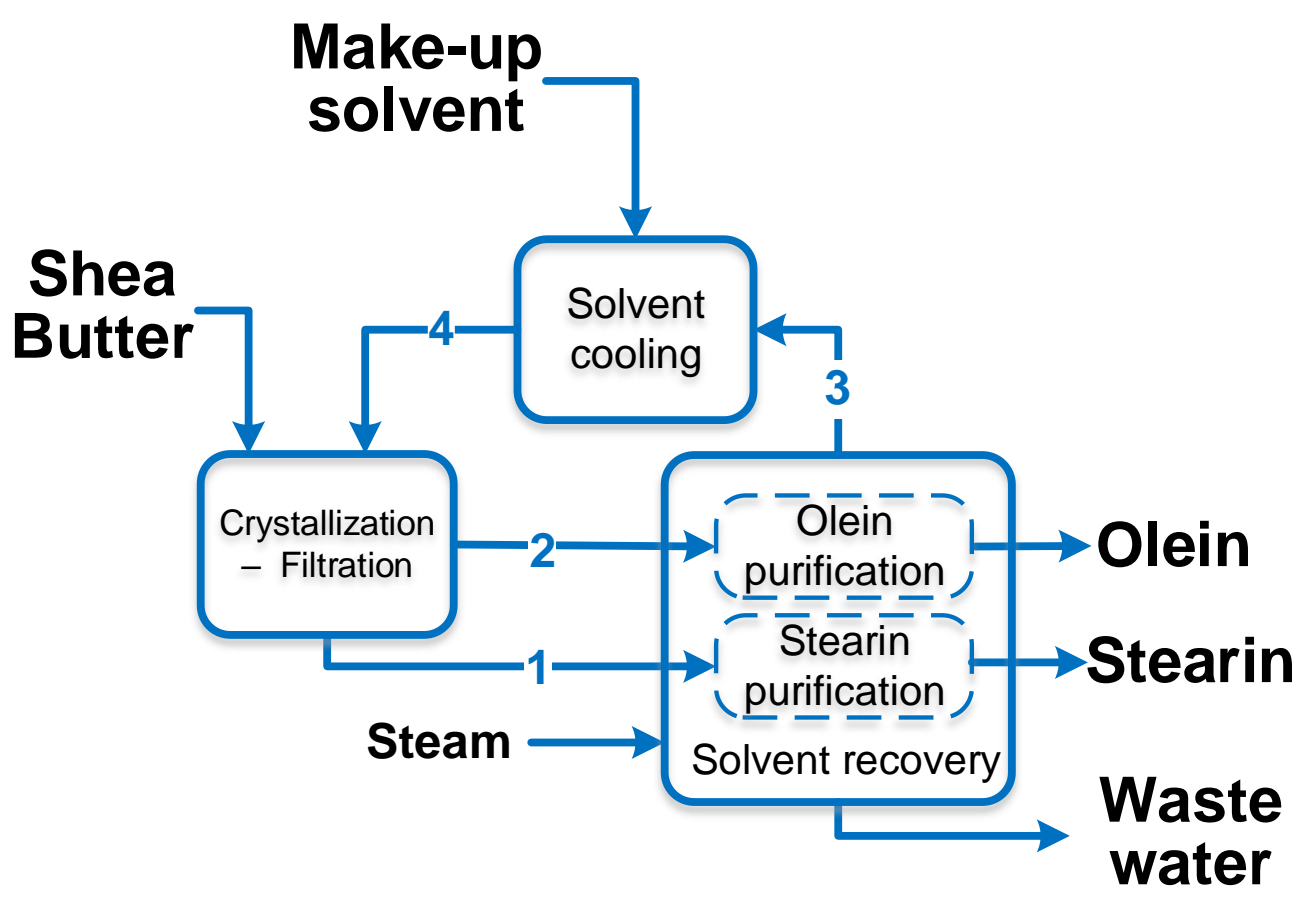

Figure 1. Shea butter acetone fractionation process simplified process flowsheet diagram.

\section{METHOD DESCRIPTION}


The testing and application of the lipid thermodynamic models are performed through process design and analysis of shea butter acetone fractionation. The study covers stages two and three of the three-stage approach from the synthesis-design-innovation framework presented by Bertran et al. $^{20}$. The three stages of the framework are (1) synthesis, (2) design, and (3) innovation. In the synthesis stage, stage one, the best processing route for a set of raw materials and products is selected. Once the processing route is established, the detailed design and process analysis are performed. This represents the second stage - design and analysis. Based on the process analysis results, more sustainable alternatives are screened within stage three - innovation stage. Methodologies for stage one and two are presented in the work of Bertram et al. (2017) and are applied in the same work and in the work of Vooradi et al. ${ }^{21}$ for an ethanol biorefinery and $\mathrm{CO}_{2}$ utilization case studies. A detailed methodology for the innovation stage, stage three, is presented by Garg et al. ${ }^{22}$ which applies each of the three stages of the framework to the bio-succinic acid production. Different stages of the framework, mostly stage one and two were applied to other studies presented in the literature (i.e. dimethyl carbonate production from $\mathrm{CO}_{2}{ }^{23}$, waste water network $^{24}$, biodiesel biorefinery ${ }^{25}$ ). For the shea butter solvent fractionation, the processing route that results from the synthesis stage, stage one of the synthesis-design-innovation framework, is already provided, and it is described in more detail in section 3.1. Together with the process requirements, operating conditions, and assumptions, the detailed design and simulation of the process are performed, followed by economic and environmental impact analysis. All these steps cover stage two, design stage, of the synthesis-design-innovation framework. Further identified hot spots are tackled for improvement and new process alternatives are generated and analysed, corresponding to stage three of the framework. 
A systematic method consisting of four steps ${ }^{26}$ is used to perform the work of stage two (steps 1-2) and stage three (step 4) of the framework. The steps of the method are (1) problem definition and process data collection, (2) process modelling, design and simulation, (3) process performance analysis (e.g. energy, economic and environmental analysis), and (4) process hot-spots identification and retrofit solutions. The work and information flow together with the tools used in each step of the method are presented in Figure 2.

\subsection{Problem definition and data collection}

The problem definition and process data collection step covers the following actions: definition of the problem to be solved, definition of the process and final product(s) specifications (e.g. feed composition, solvent ratio, separation factors, impurities content in the final product, etc.), collection of other support data needed for modelling (e.g. thermodynamic data) from industrial sources or literature.

\subsection{Process modelling, design and simulation}

In the second step of the method, detailed models of the involved unit operations are employed to perform the design and simulation of the process. Modelling and design follow well-established methods. $^{27}$

\subsection{Process analysis}

The results from process modelling, design and simulation are used in this step for the evaluation of process performance.

The economic analysis is performed with ECON and gives information on equipment cost, capital cost, operation cost and economic analysis. The economic model implemented in the software is based on the economic evaluation presented by Peters et al. ${ }^{28}$ 
The environmental impact is evaluated with $\mathrm{LCSoft}^{29}$ using the Life Cycle Analysis framework. According to the International Standardization Organization (ISO) directive ISO $14040^{30}$, the LCA consists in four steps: (1) goal and scope definition, (2) life cycle inventory (LCI) evaluation, (3) life cycle impact assessment (LCIA), and (4) results analysis and interpretation. In the first step the boundary of the system is defined (e.g. input streams, products, waste streams, utilities). The mass balance and energy balance are used in the second step to calculate the LCI. LCI database from LCSoft has information from US LCI database ${ }^{31}$ and other open sources. The LCI results are used in the third step for different environmental impact indicator calculations (e.g.: global warming potential (GWP), human toxicity potential indicator (HTPI), etc.). In the final step, the results are analysed for identifying possibilities for improvement.

The results from steps 1-3, stage two of the synthesis-design-innovation framework, represent the base case scenario.

\subsection{Process hot-spots identification and retrofit solutions}

In the final step, improved solutions are proposed based on the identified hot-spots from the economic and environmental impact analysis of step 3. Candidate solutions that represent new process alternatives cover aspects of heat integration, intensification, advanced optimization, or other retrofit solutions that match the desired targets for improvement. The economic and environmental impact performance of the new and improved alternatives are assessed and compared with the base case scenario. This step represents stage three, innovation stage, of the synthesis-design-innovation framework ${ }^{20}$. 


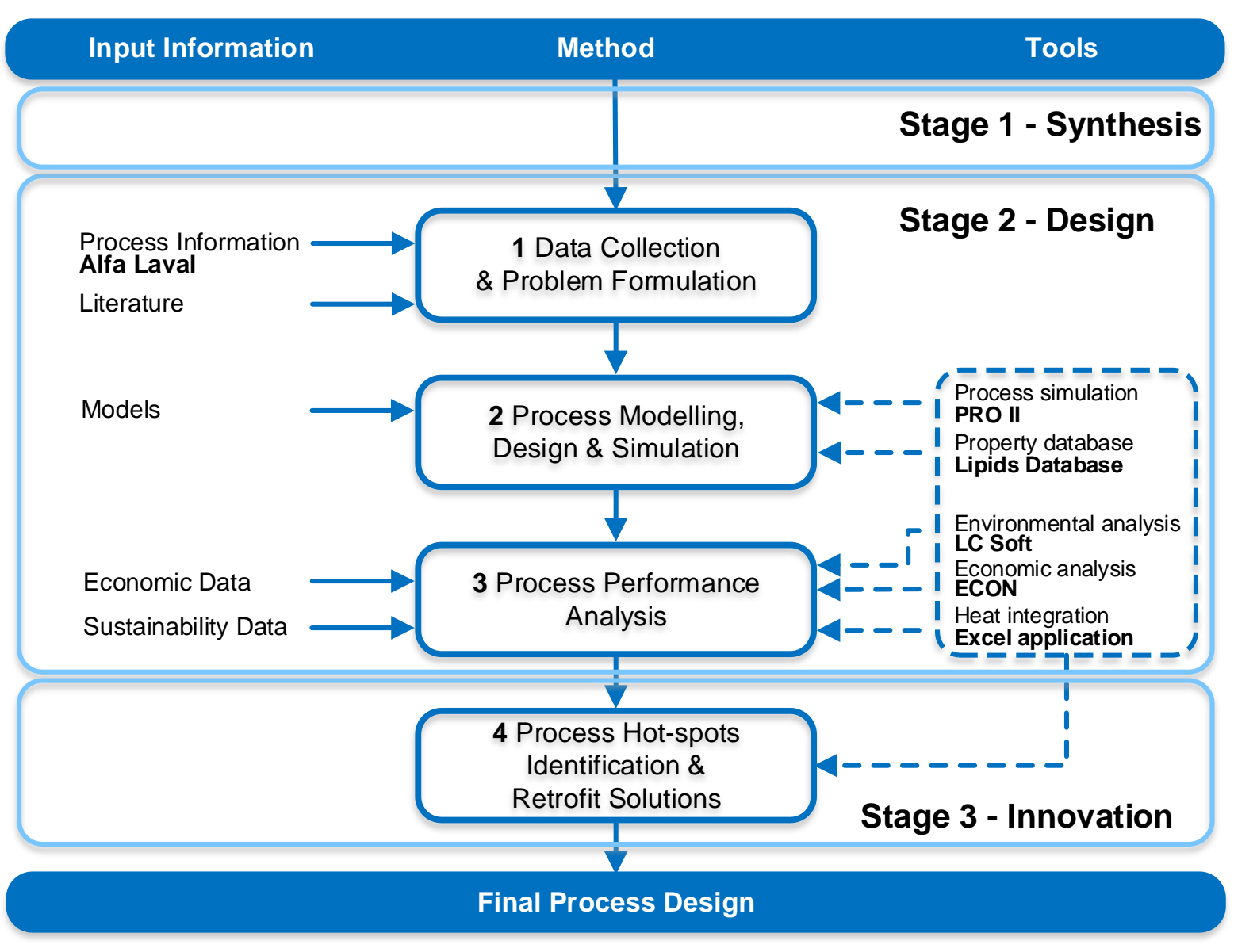

Figure 2. Generic systematic method used for process design and analysis of shea butter acetone fractionation including the representation of the three-stage approach of synthesis-designinnovation framework from Bertran et al. ${ }^{20}$

\section{RESULTS AND DISCUSSION}

In this section, the details of the method application to shea butter acetone fractionation process are given, highlighting the application of the lipid-based thermodynamic models, as well as the design-innovation methods and tools used. The results obtained in each of the four steps are presented and analysed in detail.

\subsection{Problem definition and process data collection}


The problem to be solved is to design a process for solvent fractionation for a $2000 \mathrm{~kg} / \mathrm{h}$ feed of shea butter. The final product specification should consider the following: $<1 \mathrm{mg}$ acetone $/ \mathrm{kg}$ product and $<0.5 \%$ water. The process flowsheet diagram and the main process specifications are provided by Alfa Laval. The remaining required information is taken from literature or is covered by using well-established design principles (e.g.: mass and energy balance, thermodynamic feasibility, cost and environmental impact minimisation, etc.). The process description, including process parameters and assumptions, is given in the text below. The process and products specifications are given in Table 1. The detailed stream compositions are presented in the Supporting Information.

Shea butter might come with a water content of a maximum $0.5 \%$. In this case, it is assumed that shea butter is dried before entering the process. The drying process is not considered in the current analysis. The shea butter is heated at $50^{\circ} \mathrm{C}$ in E00 heat exchanger (Figure 3) to melt the crystals and to erase the thermal history ${ }^{17}$. Next, shea butter is mixed in the crystallizer (R01) with high purity acetone in a 1:4 ratio. The crystallization process takes place at $-5^{\circ} \mathrm{C}$ in a stirred crystallizer. The two products: Stearin (solid) and Olein (liquid) are separated by filtration (F01) and washed with acetone. Any impurities in the solvent, as well as water content above $0.5 \%$, can affect the crystallization process and change the product properties (e.g. narrow melting profile, a melting point within $32-37^{\circ} \mathrm{C}$ interval) $)^{32}$ thus the need to use a high purity solvent. The solvent selection has an important impact on the separation process and depends on the quality of the oil (e.g. free fatty acids content). A polar solvent like acetone has a higher degree of separation for the polar compounds (e.g. fatty acids, diglycerides) in the liquid fraction (i.e. olein) compared to a non-polar solvent (e.g. hexane). This results in a solid product (i.e. stearin) with higher TAGs content and with no need for an extra refining step to remove the free fatty acids or other polar species. ${ }^{17}$ The 
presence of several polar compounds in the shea butter (e.g. FAs, DAGs) justifies the selection of acetone as the solvent to be used. After the fractionation, stream $05 \mathrm{~A}$ containing the stearin fraction is melted in a heat exchanger (E05A) with low pressure (LP) steam. Further, flash units (C05, C06, C07) operating under different conditions, as listed in Table 1, aim to maximize the solvent recovery from each of the two products. The residual acetone is removed from the final product by steam stripping ( $\mathrm{S} 02)$. The acetone from the vapour streams of the stripping units ( $\mathrm{S} 01$ and $\mathrm{S} 02$ ) and the flash units $\mathrm{C} 04$ and $\mathrm{C} 07$ is recovered in the acetone-water distillation column (T01). The column working pressure (i.e. 0.2 bar) is selected to maximize acetone recovery in the recycled stream (T01Top). The water separated in the bottom product (Waste water) is considered as a waste stream and its treatment is not taken into account within the process analysis. A significant amount of water that is recycled in the process is evaporated in the flash units C01 and C05. To avoid the water accumulation in the process, the vapour stream of the $\mathrm{C} 05$ unit for stearin purification (05Vap) is split into two streams: one stream (05VapColA) is fed in the distillation column, while the other is recycled. All the vapour streams from the remaining flash units $(\mathrm{C} 01$, $\mathrm{C} 02, \mathrm{C} 03$ and $\mathrm{C} 06$ ) are recycled directly into the process. Before the recycle, the acetone is cooled at $-15{ }^{\circ} \mathrm{C}$. The cooling is performed in a refrigeration cycle with ammonia $\left(\mathrm{NH}_{3}\right)$ which involves a single compression stage and is represented in the PFD through the E14 heat exchanger. 


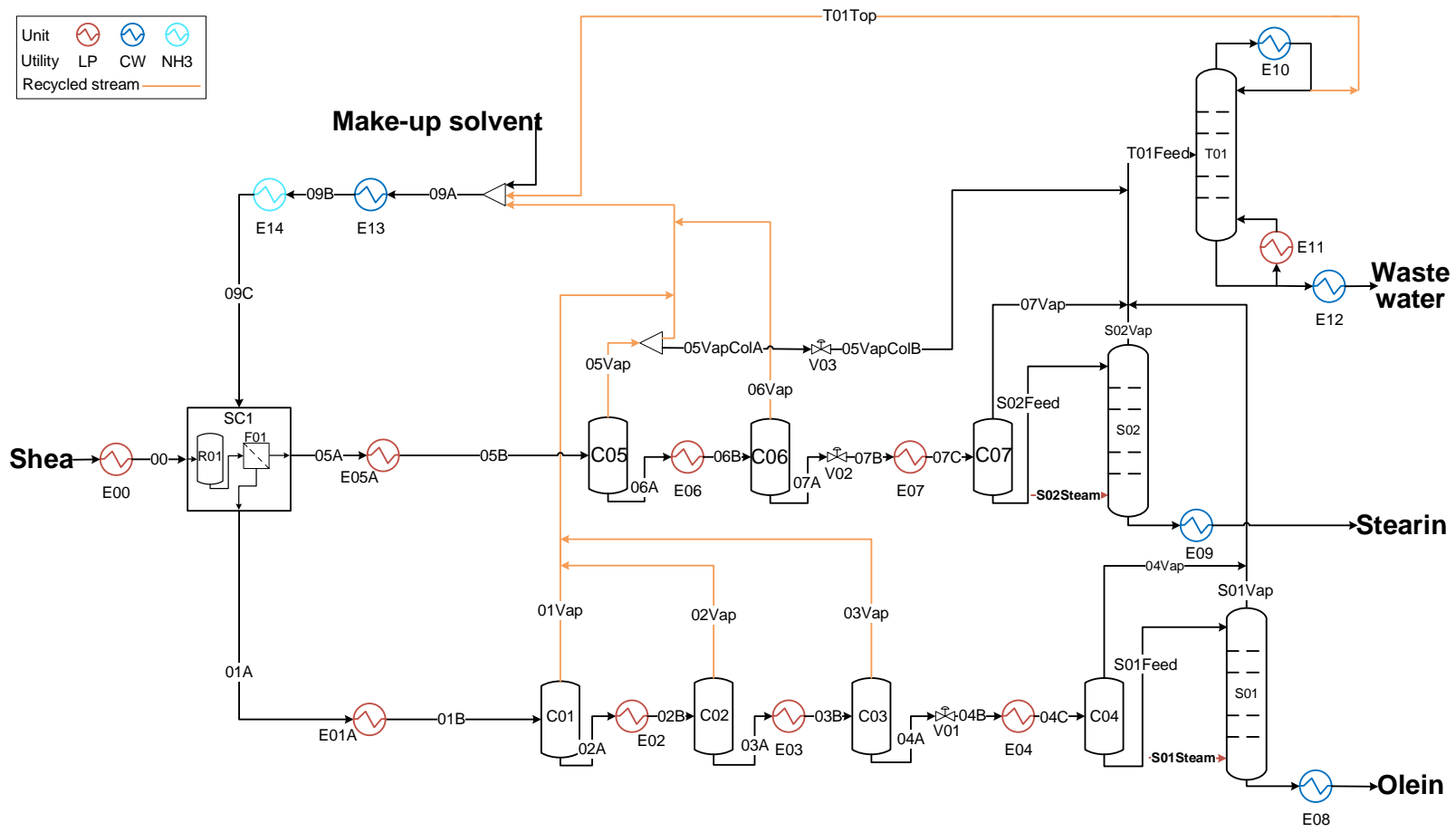

Figure 3. Shea butter acetone fractionation process flowsheet diagram for Base case scenario.

Table 1. Process specifications for the Base case scenario.

\begin{tabular}{llll}
\hline Name & Parameter & Unit & Value \\
\hline Stream & & & \\
\hline Shea & Flowrate & $\mathrm{kg} / \mathrm{h}$ & 2000 \\
\hline Acetone Make up & Flowrate & wt. ratio & $1: 4$ \\
\hline Stearin & Water content & $\%$ & $<0.5$ \\
\hline Stearin & Acetone content & mg acetone $/ \mathrm{kg}$ & $<1$ \\
& & product & \\
\hline Olein & Water content & $\%$ & $<0.5$ \\
\hline Olein & Acetone content & $\begin{array}{l}\text { mg acetone } / \mathrm{kg} \\
\text { product }\end{array}$ & $<1$ \\
\hline Unit Operation & & & \\
\hline SC1 & & ${ }^{\circ} \mathrm{C}$ & -5 \\
\hline SC1 & Crystallization temperature & wt. $\%$ & 0.5 \\
\hline $05 \mathrm{~A}$ & Stearin yield & wt. fr. & \\
\hline
\end{tabular}




\begin{tabular}{|c|c|c|c|}
\hline $\begin{array}{l}\mathrm{C} 01, \mathrm{C} 02, \mathrm{C} 03, \mathrm{C} 05, \\
\mathrm{C} 06\end{array}$ & Pressure & bar & 1 \\
\hline $\mathrm{C} 04, \mathrm{C} 07$ & Pressure & bar & 0.2 \\
\hline $\mathrm{C} 01$ & Temperature & ${ }^{\circ} \mathrm{C}$ & 56.5 \\
\hline $\mathrm{C} 02$ & Temperature & ${ }^{\circ} \mathrm{C}$ & 61.8 \\
\hline $\mathrm{C} 03$ & Temperature & ${ }^{\circ} \mathrm{C}$ & 74.5 \\
\hline C04 & Temperature & ${ }^{\circ} \mathrm{C}$ & 79.3 \\
\hline $\mathrm{C} 05$ & Temperature & ${ }^{\circ} \mathrm{C}$ & 60.1 \\
\hline C06 & Temperature & ${ }^{\circ} \mathrm{C}$ & 72.6 \\
\hline $\mathrm{C} 07$ & Temperature & ${ }^{\circ} \mathrm{C}$ & 75.8 \\
\hline SP1 & $\begin{array}{l}\text { Split fraction } \\
\text { (05VapColA/05Vap) }\end{array}$ & wt.fr. & 0.15 \\
\hline S01 & $\begin{array}{l}\text { Acetone recovery in top product } \\
\text { (S01Vap) }\end{array}$ & wt.fr. & 0.9999 \\
\hline S02 & $\begin{array}{l}\text { Acetone recovery in top product } \\
\text { (S02Vap) }\end{array}$ & wt.fr. & 0.9999 \\
\hline T01 & Pressure & bar & 0.2 \\
\hline T01 & $\begin{array}{l}\text { Acetone recovery in top product } \\
\text { (T01Top) }\end{array}$ & wt. fr. & 0.9999 \\
\hline T01 & Reflux ratio & & 2.5 \\
\hline \multicolumn{4}{|l|}{ Utility } \\
\hline LP Steam & Pressure & bar & 4 \\
\hline Process steam & Pressure & bar & 1 \\
\hline Cooling water & Supply temperature & ${ }^{\circ} \mathrm{C}$ & 20 \\
\hline Cooling water & Target temperature & ${ }^{\circ} \mathrm{C}$ & 30 \\
\hline Ammonia Cooling & Temperature & ${ }^{\circ} \mathrm{C}$ & -15 \\
\hline
\end{tabular}

\subsection{Process modelling, design and simulation}

The process model is implemented in PRO/II $10.2^{33}$. The Lipids Database, described in more detail elsewhere ${ }^{2}$, is linked to PRO/II and provides easy access to all the thermo-physical data and models needed for the simulation. This includes primary properties (e.g.: molecular weight, critical 
temperature, pressure and volume, melting temperature, formation and fusion enthalpy, Gibbs enthalpy), secondary properties (e.g.: solubility, specific gravity, compressibility factor, etc.) data and functional properties (e.g.: vapour pressure, density, viscosity, phase enthalpy) correlations. The detailed list of properties for pure compounds and mixtures used in the simulation are given in the Supporting Information. Ideal gas is assumed to describe the vapour phase, while the liquid phase is modelled with the Original UNIFAC model using the lipid-based parameters ${ }^{34}$. The missing binary interaction parameters from the lipid-based parameter matrix (i.e. parameters involving following groups $\left.\mathrm{H}_{2} \mathrm{O}, \mathrm{CH}_{2} \mathrm{CO}, \mathrm{OH}\right)$ are taken from first-order KT-UNIFAC ${ }^{35}$. The model performance with selected parameters is tested for VLE description of three systems involved in the mixture for which experimental data is available. The tested systems are acetone triolein and acetone - oleic acid at $318.15 \mathrm{~K}$ and acetone-water at different pressures. The average relative deviation for the two lipid systems shows a good agreement between predicted and experimental data. The results are presented in Table 2. The evaluation of the water-acetone system, presented in Figure 4, shows good prediction for the data sets at $101 \mathrm{kPa}$, and slight deviations for the data set at $20 \mathrm{kPa}$. This is explained by the quality of the experimental data, where the overall quality factor ${ }^{36}$ is $\mathrm{Q}=1, \mathrm{Q}=0.95$ for data at $101 \mathrm{kPa}^{37,38}$ and $\mathrm{Q}=0.23$ for data at $20 \mathrm{kPa}^{39}$. The VLE for water-acetone system was modelled also with NRTL using the parameters implemented in PRO II. Performance similar to UNIFAC model was achieved. More details can be found in Supporting Information. Examples of model performance for other lipid mixtures can be found in the work of Perederic et al. ${ }^{2,34}$. The parameter matrix used in the simulation is provided in Supplementary Information.

Table 2. Original UNIFAC model with lipid-based parameters performance for acetone-lipid systems. 


\begin{tabular}{|c|c|c|c|c|c|c|c|}
\hline \multicolumn{4}{|c|}{ Acetone (1) - Triolein (2) at $\mathrm{T}=318.15 \mathrm{~K}^{\mathrm{a}}$} & \multicolumn{4}{|c|}{ Acetone (1) - Oleic acid (2) at $\mathrm{T}=318.15 \mathrm{~K}^{\mathrm{a}}$} \\
\hline $\mathrm{x}_{1}$ & $\mathrm{P}_{\exp }, \mathrm{kPa}$ & $\mathrm{P}_{\text {calc }}, \mathrm{kPa}$ & $\mathrm{ARD}^{\mathrm{b}}$ & $\mathrm{x}_{1}$ & $\mathrm{P}_{\text {exp }}, \mathrm{kPa}$ & $\mathrm{P}_{\text {calc }}, \mathrm{kPa}$ & $\mathrm{ARD}^{\mathrm{b}}$ \\
\hline 0.099 & 6.15 & 3.68 & $1.99 \%$ & 0.031 & 2.86 & 1.76 & $2.10 \%$ \\
\hline 0.169 & 10.60 & 6.57 & & 0.056 & 5.16 & 3.21 & \\
\hline 0.241 & 15.30 & 9.84 & $\mathrm{Q}^{\mathrm{c}}$ & 0.082 & 7.43 & 4.75 & $\mathrm{Q}^{\mathrm{c}}$ \\
\hline 0.318 & 20.33 & 13.69 & 0.476 & 0.117 & 10.45 & 6.85 & 0.5 \\
\hline 0.396 & 25.54 & 18.05 & & 0.211 & 17.96 & 12.77 & \\
\hline 0.523 & 34.26 & 26.26 & & 0.309 & 25.28 & 19.33 & \\
\hline 0.631 & 41.78 & 34.55 & & 0.421 & 33.73 & 27.29 & \\
\hline 0.749 & 50.05 & 45.09 & & 0.471 & 36.58 & 30.99 & \\
\hline 0.811 & 54.45 & 51.17 & & 0.598 & 44.75 & 40.67 & \\
\hline 0.895 & 60.55 & 59.51 & & 0.728 & 52.84 & 50.62 & \\
\hline 0.941 & 63.89 & 63.72 & & 0.836 & 58.98 & 58.31 & \\
\hline \multirow[t]{2}{*}{1} & 68.17 & & & 0.947 & 65.10 & 64.99 & \\
\hline & & & & 1 & 68.10 & 68.10 & \\
\hline
\end{tabular}

${ }^{\mathrm{a}}$ Data from Eduljee and Boyes ${ }^{40}$

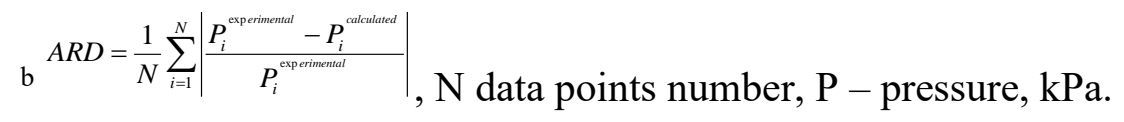

${ }^{\mathrm{c}} \mathrm{Q}$ - quality factor of the datasets evaluated with the algorithm proposed by Kang et al. ${ }^{36}$ and implemented in $\mathrm{TDE}^{41}$ 


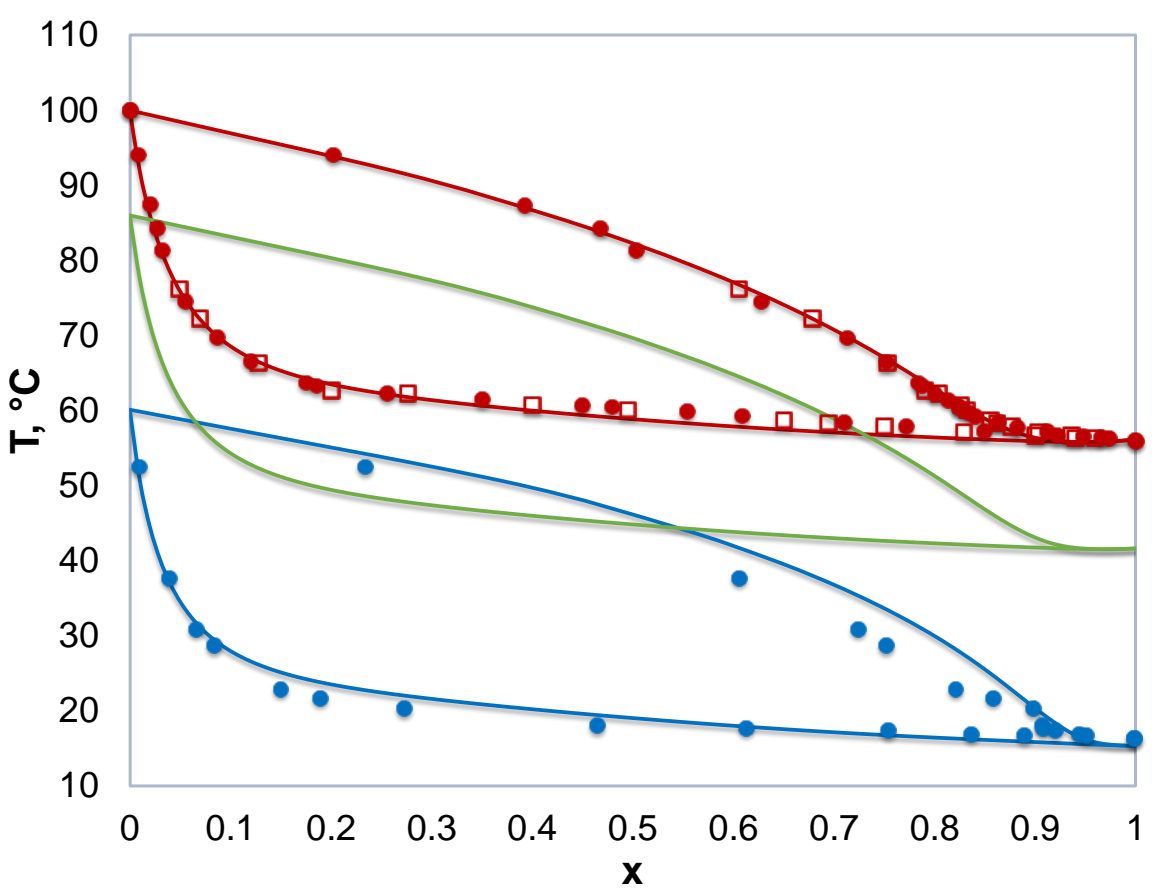

Figure 4. Acetone-water vapor liquid equilibria model prediction and experimental data. Original UNIFAC with lipid-based parameters and KT UNIFAC parameters prediction: - 101.33 $\mathrm{kPa},-60 \mathrm{kPa},-20 \mathrm{kPa}$. Experimental data: $\left.101.33 \mathrm{kPa}^{37}, \square 101.33 \mathrm{kPa}^{38}, \bullet 20 \mathrm{kPa}^{39}\right)$.

The feed composition for shea butter is given by Alfa Laval. The acetone used in the process is assumed to be of high purity. The composition of Shea and Make-up solvent are given in Table 3.

There is a vast literature were various experimental studies for oil and fats crystallization with focus on specific binary or multicomponent systems are conducted, but limited data can be found for shea oils and its products ${ }^{14,42-44}$. Regarding the modelling aspects, several models for solidliquid equilibria modelling ${ }^{45-47}$, simple crystallization kinetics ${ }^{48,49}$ (e.g.: Avrami and AvramiErofeev models ${ }^{50-53}$, Gompertz model $^{54,55}$, Foubert model ${ }^{56}$ ) or crystallization in the presence of a solvent ${ }^{57}$ were developed and improved over the years. Each of these models requires a significant amount of experimental data to describe a certain mixture of lipids, many of them requiring 
knowledge on the SLE of the binary systems involved in the mixtures. In the Supporting information we have gathered all the binary SLE data available for the compounds of the shea oil feed (Shea stream) used in this work, and which cover less than $10 \%$ of the total number of binary systems involved. A systematic approach is used by Hjorth et al. ${ }^{58,59}$, which developed a complex framework for thermodynamic and crystallization kinetics modelling of triacylglycerides mixtures. Even though the model is predictive and does not require knowledge of binary SLE of involved compounds, a set of appropriate experimental is needed to fit the model parameters. Given the limited available data for the considered mixture, a simple mass balance model (SC1) is used to describe the crystallization (R01), filtration and washing operations (F01) presented in Figure 3. The data used for these operations is industrial data provided by Alfa Laval. The crystallizer duty is estimated from the heat of formation of each compound separated in the stearin product (stream 05A). The energy balance for the crystallizer is provided in the Supporting information. The values for the heat of formation were taken from the Lipids Database. The temperatures in the flash units are selected based on the amount of acetone to be separated from the mixture and the product temperature limit for degradation, which was determined by the presence of unsaturated lipid compounds and which should not exceed $110{ }^{\circ} \mathrm{C}$. Selected specifications are listed in Table 1. The stripping units (S01 and S02) are modelled with six equilibrium trays. The top pressure is set at 0.2 bar and the set pressure drop is 0.01 bar per tray. The process steam stream (S01Steam, S02Steam) is fed below the bottom tray and the stream containing the final product (S01Feed, S02Feed) is fed on the top tray. Acetone recovery in the top product of the stripping units is set as specification. The pressure in the distillation column (T01) is set to 0.2 bar. This selection is made by considering the amount of water to be removed from the process and the behaviour of the acetone-water mixture at different pressures (see Figure 


\begin{tabular}{|c|c|c|c|c|c|c|c|c|}
\hline DAGs, kg/h & 20.0 & 0 & 0 & 0 & 0 & 9.4 & 10.6 & 0 \\
\hline MAGs, $\mathrm{kg} / \mathrm{h}$ & 1.6 & 0 & 0 & 0 & 0 & 0.8 & 0.8 & 0 \\
\hline FAs, $\mathrm{kg} / \mathrm{h}$ & 200.1 & 0 & 0 & 0 & 0 & 28.2 & 171.9 & 0 \\
\hline Minors $^{\mathrm{a}}, \mathrm{kg} / \mathrm{h}$ & 8.5 & 0 & 0 & 0 & 0 & 4 & 4.5 & 0 \\
\hline Acetone, $\mathrm{kg} / \mathrm{h}$ & 0 & 0.3 & 0 & 0 & 284.5 & 0 & 0 & 0.3 \\
\hline Water, $\mathrm{kg} / \mathrm{h}$ & 0 & 0 & 16.8 & 13.2 & 25.5 & 2.6 & 3.3 & 24.3 \\
\hline $\begin{array}{l}{ }^{\mathrm{a}} \text { Minors }-\mathrm{t} \\
{ }^{\mathrm{b}} \text { Flowrates }\end{array}$ & $\begin{array}{l}\text { opherols, } \\
\text { compone }\end{array}$ & $\begin{array}{l}\text { sterols a } \\
\text { nts small }\end{array}$ & $\begin{array}{l}\text { d squalen } \\
\text { r than } 10^{-}\end{array}$ & $\mathrm{g} / \mathrm{h}$ are & presente & in the $t$ & e with & \\
\hline Table 4. Ener & balance $\mathrm{f}$ & or the $\mathrm{Ba}$ & e case and & lternat & s $1-3$ of & ea butte & cetone & ctions \\
\hline process. & & & & & & & & \\
\hline Unit Name & Base cas & & Alternat & & Alternat & & Alterna & \\
\hline & $\begin{array}{l}\text { Duty, } \\
\mathrm{kW}\end{array}$ & Utility & $\begin{array}{l}\text { Duty, } \\
\mathrm{kW}\end{array}$ & Utility & $\begin{array}{l}\text { Duty, } \\
\mathrm{kW}\end{array}$ & Utility & $\begin{array}{l}\text { Duty, } \\
\mathrm{kW}\end{array}$ & Utility \\
\hline E00 & 32.77 & LP & 32.77 & - & 32.77 & - & 32.77 & - \\
\hline E01A & 807.83 & LP & 272.44 & - & 272.44 & - & 272.44 & - \\
\hline E01B & - & & 535.38 & LP & 22.11 & - & 22.11 & - \\
\hline E02 & 461.81 & LP & 461.81 & LP & 394.44 & - & 394.44 & - \\
\hline E03 & 45.59 & LP & 45.59 & LP & 423.54 & LP & 423.54 & LP \\
\hline E04 & 16.55 & LP & 16.55 & LP & 8.95 & $\mathrm{CW}$ & 8.95 & $\mathrm{CW}$ \\
\hline E05A & 160.21 & LP & 65.75 & - & 65.75 & - & 65.75 & - \\
\hline E05B & - & & 94.45 & LP & 67.27 & - & 67.27 & - \\
\hline E06 & 50.68 & LP & 50.68 & LP & 100.73 & LP & 100.73 & LP \\
\hline E07 & 14.02 & LP & 14.02 & LP & 15.92 & LP & 15.92 & LP \\
\hline E08 & 28.44 & $\mathrm{CW}$ & 28.44 & $\mathrm{CW}$ & 28.45 & $\mathrm{CW}$ & 46.34 & $\mathrm{CW}$ \\
\hline E09 & 16.83 & $\mathrm{CW}$ & 16.83 & $\mathrm{CW}$ & 16.83 & $\mathrm{CW}$ & 16.83 & $\mathrm{CW}$ \\
\hline E10 & 154.65 & $\mathrm{NH}_{3}$ & 154.65 & $\mathrm{NH}_{3}$ & 171.36 & $\mathrm{NH}_{3}$ & 168.5 & $\mathrm{NH}_{3}$ \\
\hline E11 & 88.59 & LP & 88.59 & LP & 100.02 & LP & 118.7 & LP \\
\hline E12 & 1.21 & $\mathrm{CW}$ & 1.21 & $\mathrm{CW}$ & 1.21 & $\mathrm{CW}$ & - & - \\
\hline E13 & 1236.63 & $\mathrm{CW}$ & 865.67 & $\mathrm{CW}$ & 522.03 & $\mathrm{CW}$ & 522.84 & $\mathrm{CW}$ \\
\hline
\end{tabular}




\begin{tabular}{|c|c|c|c|c|c|c|c|c|}
\hline E14 & 210.83 & $\mathrm{NH}_{3}$ & 210.83 & $\mathrm{NH}_{3}$ & 210.4 & $\mathrm{NH}_{3}$ & 210.4 & $\mathrm{NH}_{3}$ \\
\hline E15 & - & & - & & - & & 4.93 & $\mathrm{NH}_{3}$ \\
\hline E16 & - & & - & & - & & 5.21 & LP \\
\hline R01 & 43.45 & $\mathrm{NH}_{3}$ & 43.45 & $\mathrm{NH}_{3}$ & 43.45 & $\mathrm{NH}_{3}$ & 43.45 & $\mathrm{NH}_{3}$ \\
\hline Total Cold Utility & 1692.04 & $\begin{array}{l}\mathrm{CW}, \\
\mathrm{NH}_{3}\end{array}$ & 1321.08 & $\begin{array}{l}\mathrm{CW}, \\
\mathrm{NH}_{3}\end{array}$ & 1002.68 & $\begin{array}{l}\mathrm{CW}, \\
\mathrm{NH}_{3}\end{array}$ & 1022.24 & $\begin{array}{l}\mathrm{CW}, \\
\mathrm{NH}_{3}\end{array}$ \\
\hline Total Hot Utility & 1678.05 & LP & 1307.07 & LP & 640.21 & LP & 664.1 & LP \\
\hline
\end{tabular}

\subsection{Process performance analysis}

The process performance is analysed in terms of energy requirements, environmental impacts and economic performance. The total utility consumption is determined from the energy balance and requires a total of 1.69 MW for cold utilities (cooling water and ammonia cooling) and 1.68 MW for hot utilities (LP steam).

The environmental impact takes into account the effect of the waste stream, Waste water, and the effect of utilities used in the process. The following streams are considered for the analysis: Shea and Make-up solvent streams represented the input materials, Stearin and Olein were considered as product streams, and Waste water is defined as a waste stream. Following utilities and their sources are considered in the environmental impact evaluation: electricity produced from natural gas at a power plant, natural gas combusted in an industrial boiler is used for heating and chilled water is used for cooling. These utilities are taken for the LCSoft default database. The analysis provides results for seven indicators regarding air, soil and water impacts, as well as human toxicity, which are given in Table 5. A significant impact is encountered for the global warming potential indicator, or carbon footprint, which is generated by the process utilities. Acetone traces in the Waste water stream generate most of the impact for photochemical oxidation potential (i.e. 92\%) and has an important contribution to HTPE indicator (i.e. 35\%), while the impact for remaining categories comes from both the utilities and chemicals. 
Table 5. Environmental performance for the Base case and Alternatives 1-3 of shea butter acetone fractionation process.

\begin{tabular}{llllll}
\hline Indicator & Unit & Base case & Alternative 1 & Alternative 2 & Alternative 3 \\
\hline HTPI & $1 / \mathrm{LD}_{50}$ & $1.78 \cdot 10^{-2}$ & $1.80 \cdot 10^{-2}$ & $4.00 \cdot 10^{-3}$ & $1.10 \cdot 10^{-2}$ \\
\hline HTPE & $1 /$ TWA & $5.79 \cdot 10^{-5}$ & $5.60 \cdot 10^{-5}$ & $1.50 \cdot 10^{-5}$ & $3.50 \cdot 10^{-5}$ \\
\hline ATP & $1 / \mathrm{LC}_{50}$ & $3.03 \cdot 10^{-4}$ & $2.50 \cdot 10^{-4}$ & $1.10 \cdot 10^{-4}$ & $1.30 \cdot 10^{-4}$ \\
\hline PCOP & $\mathrm{C}_{2} \mathrm{H}_{2}$ eq. & $1.05 \cdot 10^{-1}$ & $1.10 \cdot 10^{-1}$ & $2.40 \cdot 10^{-2}$ & $6.78 \cdot 10^{-2}$ \\
\hline GWP & $\mathrm{CO}_{2}$ eq & 1.82 & 1.40 & 1.00 & 1.00 \\
\hline ODP & $\begin{array}{l}\mathrm{CFC}^{11} \\
\text { eq }\end{array}$ & $1.65 \cdot 10^{-10}$ & $1.30 \cdot 10^{-10}$ & $6.30 \cdot 10^{-11}$ & $6.50 \cdot 10^{-11}$ \\
\hline AP & $\mathrm{H}^{+}$eq & $8.30 \cdot 10^{-2}$ & $6.50 \cdot 10^{-2}$ & $4.10 \cdot 10^{-2}$ & $4.20 \cdot 10^{-2}$
\end{tabular}

The economic analysis uses the cost index factor ${ }^{63}$ which is updated with the latest available value. The plant running time assumed is 288 days per year. The detailed equipment design is taken into account for investment and operating costs. The ammonia refrigeration cycle and the pumps necessary for the process are considered within the economic analysis as well. The drying of shea butter and the treatment of waste stream are not considered in the analysis. The prices of the raw materials, products and utilities, given in Table 6 , are selected based on data provided by Alfa Laval, online available data and ECON data. The price for steam and water cooling is given based on energy provided, while the ammonia price is considered per amount and it is used for the cost calculation of the ammonia refrigeration cycle. The design, sizing, economic evaluation and environmental impact of the ammonia refrigeration cycle are taken into consideration in the evaluation and analysis of the results of the base case, as well as, proposed alternatives in step 4 of the method. The results of the economic analysis show a total capital investment of 4.7 M€ with a rate of return (ROR) of $22 \%$. The process break-even point is 1.8 years while the payback period is 3 years. Total operating cost is $21.18 \mathrm{M} € /$ year from which manufacturing cost covers 19.26 
$\mathrm{M} € /$ year. The cost for utilities is $0.54 \mathrm{M} € /$ year. The raw materials purchase cost accounted for $85 \%$ of the total operating costs, and it is similar to other bio-based processes (e.g. bio-diesel production $\left.{ }^{64,65}\right)$. The economic indicators from the analysis are given in Table 7.

Table 6. Prices for raw materials, products and utilities used in the economic analysis of Base case and process Alternatives 1-3.

\begin{tabular}{llll}
\hline Material & Price & Material & Price \\
\hline Shea butter & $1.3^{\mathrm{a}} € / \mathrm{kg}$ & Process water (Steam) & $0.2 € / \mathrm{kg}$ \\
\hline Stearin & $3.0 € / \mathrm{kg}$ & $\mathrm{CW}$ & $0.35 € / \mathrm{GJ}$ \\
\hline Olein & $1.5 € / \mathrm{kg}$ & LP & $7 € / \mathrm{GJ}$ \\
\hline Acetone & $2.3^{\mathrm{b}} € / \mathrm{kg}$ & Ammonia & $0.8 € / \mathrm{kg}^{\mathrm{c}}$
\end{tabular}

${ }^{a}$ Data from CBI Market Intelligence ${ }^{66}$

${ }^{b}$ High purity acetone was considered for the process ${ }^{67}$

${ }^{c}$ Data from Boulamanti and Moya ${ }^{68}$

Table 7. Economic performance for the Base case and Alternatives 1-3 of shea butter acetone fractionation process.

\begin{tabular}{lllll}
\hline Indicator & Base case & Alternative 1 & Alternative 2 & Alternative 3 \\
\hline Total Capital Investment, M€ & 4.74 & 4.82 & 4.82 & 4.76 \\
\hline Equipment Purchase Cost, M€ & 0.59 & 0.95 & 0.95 & 0.94 \\
\hline Total Production Cost, M€/year & 21.18 & 21.14 & 21.08 & 21.08 \\
\hline Manufacturing Cost, M€/year & 19.26 & 19.22 & 19.16 & 19.18 \\
\hline Raw Materials Cost, M€/year & 18.03 & 18.03 & 18.03 & 18.00 \\
\hline
\end{tabular}

\subsection{Process hot-spots identification and improvement solutions}

The analysis of the process performance indicates high utility cost as the main hot-spot of the process with emphasis on the heat exchangers E01, E02 and E14. The improvements can be achieved through process heat integration. More heat integration can be performed if the operating 
parameters of the flash units are changed. Based on the identified improvement opportunities, two process alternatives based on heat integration are developed and analysed: Alternative 1 and Alternative 2. A third alternative, Alternative 3, involving a side draw distillation column for Olein and solvent separation is investigated as well with the aim to reduce the amount of water that enters the process. The set-up and analysis of the three process alternatives are similar to the Base case scenario and follows Steps 1-3 of the method. Each of the proposed process alternatives is presented individually, highlighting the modifications and comparing the performance with the Base case scenario.

\subsubsection{Process Alternative 1}

Process Alternative 1 is based on heat integration performed for the Base case scenario. The heat integration potential is evaluated through pinch analysis ${ }^{69,70}$. All the cold and hot streams from the process are considered within the analysis. The minimum temperature difference selection considers capital cost (i.e. heat exchanger price) and operation cost (i.e. utility cost) trade-off. The evaluation with ECON of both capital and operation cost is estimated using the same prices and cost models used in the economic analysis of the Base case. Several values for minimum temperature difference are tested, and the one giving minimum total cost is selected.

The Base case scenario potential for process-to-process heat recovery for a minimum temperature difference of $5.69^{\circ} \mathrm{C}$ is $983.4 \mathrm{~kW}$. Under these conditions, the minimum hot utility requirement is $673.23 \mathrm{~kW}$ and the minimum cold utility requirement is $367.20 \mathrm{~kW}$, as shown by the shifted composite curves diagram presented in Figure 5. The pinch point is located at $57.19^{\circ} \mathrm{C}$ (i.e. $54.34^{\circ} \mathrm{C}$ for hot streams and $60.04^{\circ} \mathrm{C}$ for cold streams). The balance grand composite curve, presented in Figure 6, gave the utility placement and satisfied the minimum heat and cold utility requirements. No utility pinch point is observed in the grand composite curve. 
For reasons of process control, a sub-problem of the heat integration is considered for Alternative 1. The heat integration is performed between the acetone recycle stream (i.e stream 09A) which needed to be cool down from $60{ }^{\circ} \mathrm{C}$ to $-15^{\circ} \mathrm{C}$, the two product streams resulted after filtration (i.e. stream 01A and 05A which are cold streams), and the oil feed stream (i.e. stream Oil which is a cold stream). For this case scenario (i.e. one hot and three cold streams) two heat exchangers are added to the initial flowsheet (i.e.E01B, E05B), as presented in Figure 7, while the specifications of the heat exchangers already available (i.e. E01A, E05A, E13) are changed. Details of the modified and the new heat exchangers energy requirements are given in Table 4. For the proposed heat exchanger network (HEN) the recovered heat is $371.0 \mathrm{~kW}$, which represents $37 \%$ of the total allowed heat recovery for the Base case scenario. The heat integration leads to a $24.5 \%$ drop in cold utility consumption and $22.1 \%$ drop in hot utility consumption, which translates to a 55 $\mathrm{k} € /$ year decrease in the operating cost. In terms of environmental impact, the impact generated by the Waste water stream is the same (i.e. the composition of the stream is the same as for the Base case scenario), while the impact generated by the utilities dropped leading to a $21 \%$ smaller value for GWP indicator. The detailed results of the environmental impact are given in Table 5. The main economic indicators for Alternative 1 are listed in Table 7, indicating an increase in investment cost and a decrease in operating cost compared to the Base case scenario. 


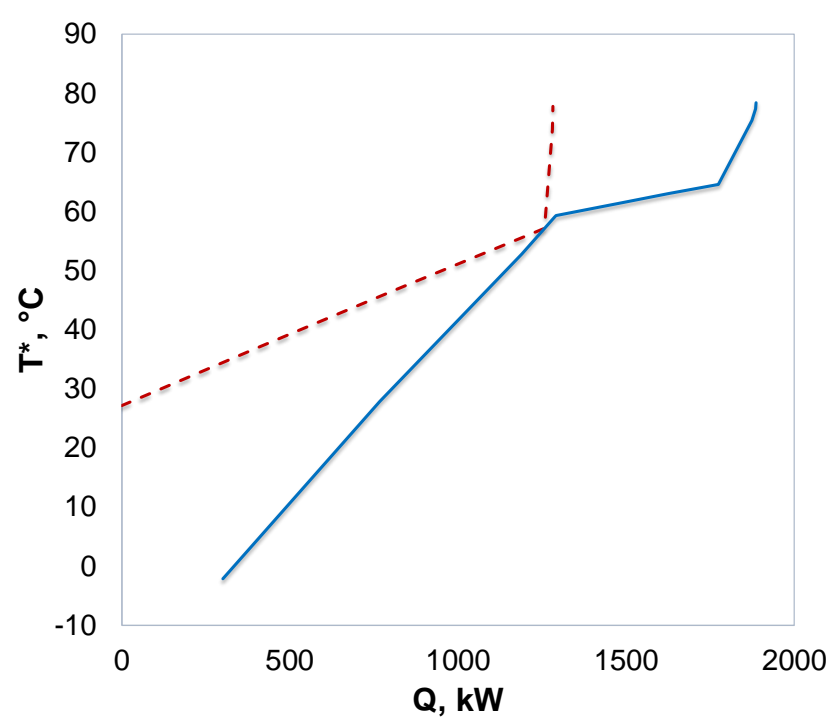

Figure 5. Shifted composite curves for the Base case scenario heat integration problem. Cold composite curve ( - ), hot composite curve ( - - ) ).

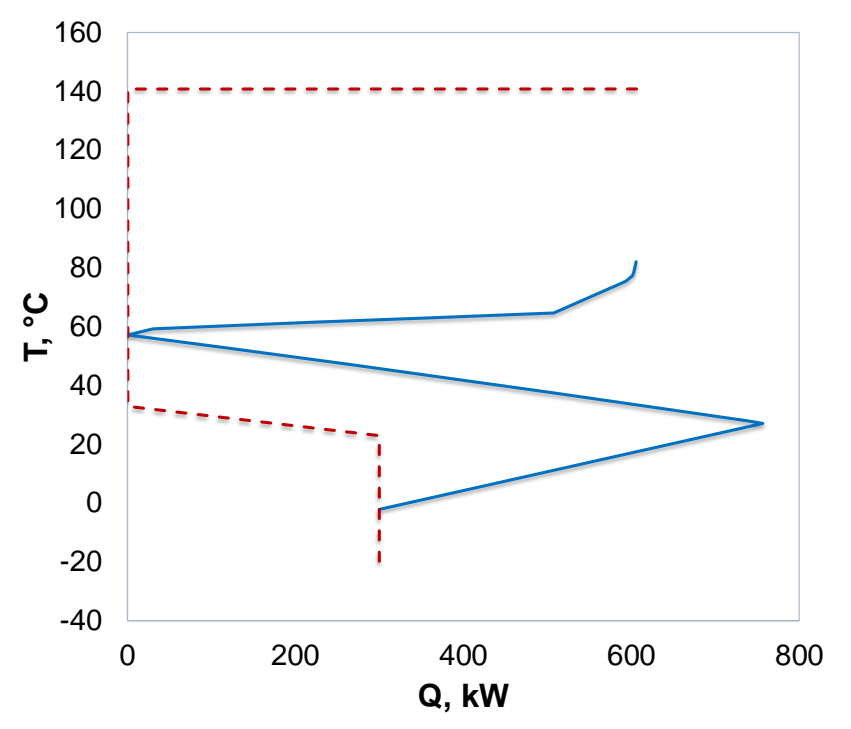

Figure 6. Process grand composite curves for the Base case scenario heat integration problem. Process grand composite curve ( - ), utility grand composite curve ( - - ). 

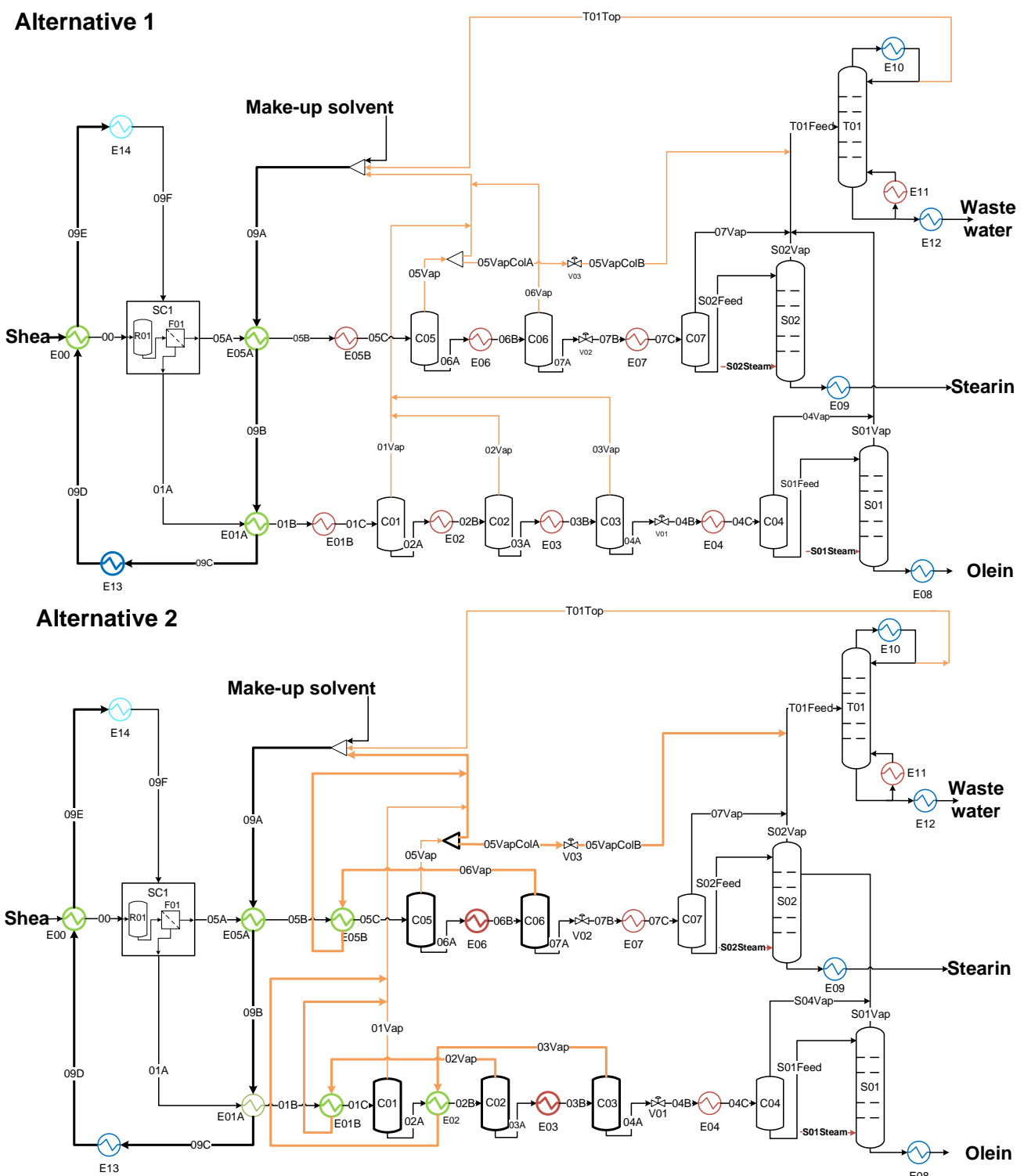

Alternative 3

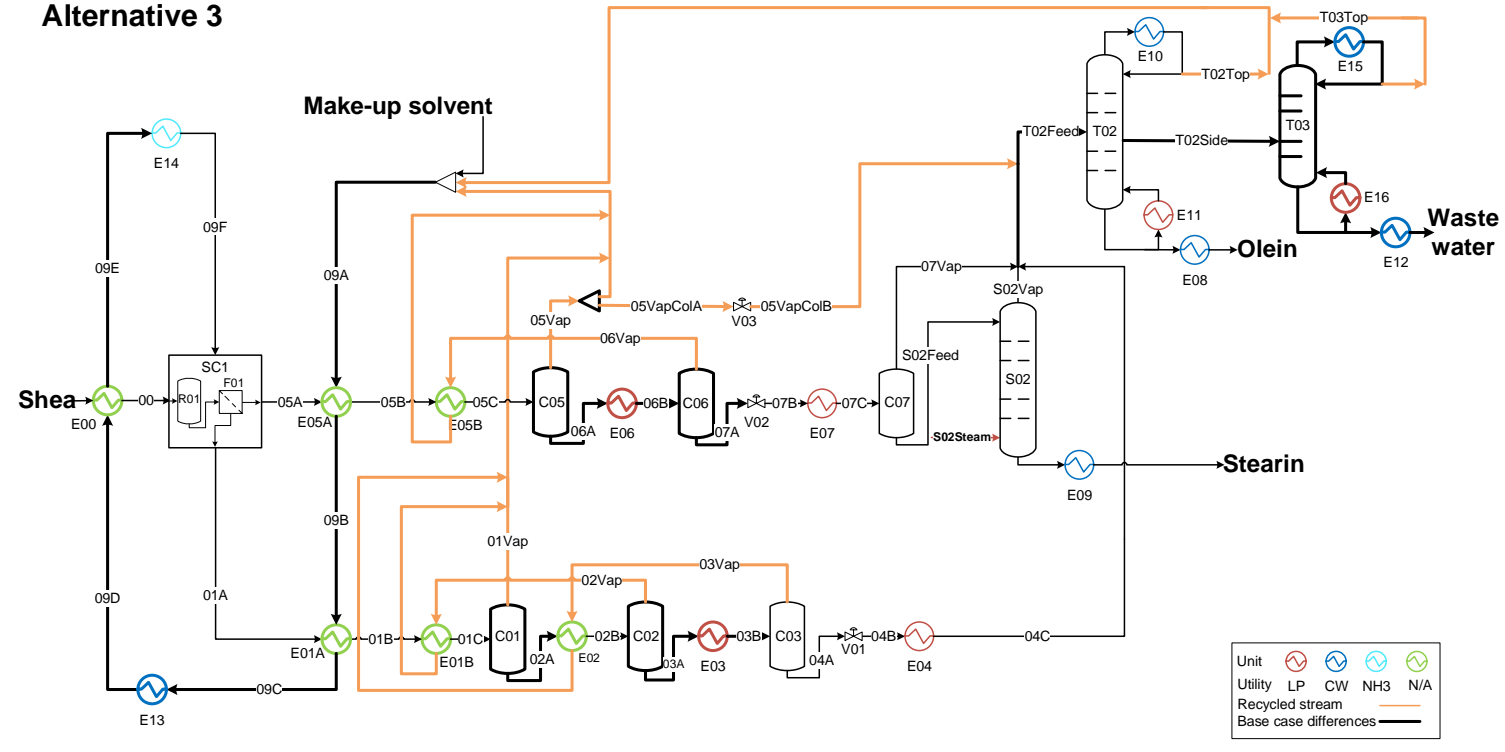

ACS Paragon Plus Environment 
Figure 7. Shea butter acetone fractionation process flowsheet diagram for Alternative 1 involving heat integration of the acetone recycle stream (09A) with the feed stream (Shea) and the two streams resulted from fractionation $(01 \mathrm{~A}, 05 \mathrm{~A})$; Alternative 2 involving heat integration of recycle stream (09A) with feed stream (Shea) and fractionation products (01A, 05A), and integration of flash vapor product stream (02Vap, 03Vap and 06Vap) with the feed stream (01C, 02A, 05C) of a previous unit; Alternative 3 involving the heat integration from Alternative 2 and implementation of side draw column T02 for separation of Olein, acetone recovery (T02Top), and water removal (Waste water).

\subsubsection{Process Alternative 2}

In Alternative 2 of the process, the flash operating conditions are modified to allow further heat integration, while the HEN developed in Alternative 1 is implemented with slight modifications of duty for E013 heat exchanger. The flash specifications are selected such as the separated acetone vapour stream is able to provide the heat for another flash unit feed (e.g. vapour stream 02Vap from $\mathrm{C} 02$ flash unit heats the feed stream $01 \mathrm{C}$ of the $\mathrm{C} 01$ flash unit) as it is presented in Figure 7. The following assumptions are made with respect to the process modifications: the pressure of the units $\mathrm{C} 04$ and $\mathrm{C} 07$ is kept at $\mathrm{P}=0.2$ bar, the specifications of strippers feed composition is the same as the Base case scenario in order to have the same amount of steam entering the process via S01 and S02, and the specifications for the final products are the same. All the new flash specifications are given in Table 8. The split factor in SP1 splitter is modified to keep the same amount of water recycled in the process as in the Base case scenario.

The energy balance for Alternative 2 is given in Table 4 . The heat recovered within the process is $854.8 \mathrm{~kW}$, equivalent $87 \%$ of the total heat recovery given by the pinch analysis of the Base case scenario. The utility requirements decrease by $47 \%$ for cold utilities and by $61 \%$ for hot utility, 
corresponding to a $153 \mathrm{k} € /$ year drop in operating costs. The reduced utility consumption has an effect on the environmental impact as well. The GWP indicator value decreases by $43 \%$ compared to the Base case scenario and by $30 \%$ compared to Alternative 1 . Detailed results of the environmental impact of Alternative 2 are given in Table 5.

Table 8. Specifications for flash units from process Alternative 2.

\begin{tabular}{lll}
\hline Unit & Pressure, bar & Temperature, ${ }^{\circ} \mathrm{C}$ \\
\hline $\mathrm{C} 01$ & 1 & 56.25 \\
\hline $\mathrm{C} 02$ & 2 & 78.55 \\
\hline $\mathrm{C} 03$ & 2.3 & 107.6 \\
\hline $\mathrm{C} 04$ & 0.2 & 79.32 \\
\hline $\mathrm{C} 05$ & 1 & 58.85 \\
\hline $\mathrm{C} 06$ & 2 & 99.08 \\
\hline $\mathrm{C} 07$ & 0.2 & 75.77 \\
\hline
\end{tabular}

\subsubsection{Process Alternative 3}

Another alternative of the process, which involves a side-draw column, is investigated. The column aim is to separate the olein product and the solvent. The side draw column (T02) replaces C04 flash and S01 stripping column units, as presented in Figure 7. The design of the column is performed with the driving force method ${ }^{60}$ resulting in a column with 15 theoretical trays, feed on tray number 8 , and side draw on tray number 11 . The side-draw stream, composed of $50 \%$ water and $50 \%$ acetone, is further separated in a distillation column (T03), where the water is discarded as Waste water and the acetone (T03Top) is recycled. Note that the flowrate of T03 column feed stream is significantly smaller compared to the feed of T01 distillation column. The set-up of T03 distillation column (e.g. operating conditions and specifications) is similar to the distillation column from Base case (T01). The heat integration of the flash units and the other heat exchangers 
are implemented as presented in Alternative 2. The mass and energy balance for Alternative 3 are given in Table 9 and Table 4. The results for environmental analysis, and economic analysis, presented in Table 5 and Table 7, indicate performances close to those of Alternative 2: slight improvements for investment costs, a slight increase in operation cost and a slight increase for several environmental impact categories. Better acetone recovery and less process steam have a positive impact also on the raw material purchase cost, slightly lower than Base case scenario, Alternative 1 and Alternative 2, as given in Table 7. The comparison between the three process alternatives to the Base case scenario shows a significant improvement for the proposed process alternatives, with the best performances being achieved for Alternative 2. An overview of the performances of Alternatives 1-3 reported to the Base case scenario is given in Figure 8, where the indicators values from the plot are normalized to the Base case scenario results.

Table 9. Mass balance for process Alternative 3 of shea butter acetone fractionation.

\begin{tabular}{|c|c|c|c|c|c|c|c|}
\hline Stream & Shea & $\begin{array}{l}\text { Make-up } \\
\text { solvent }\end{array}$ & S02Steam & Stearin & Olein & T02Side & $\begin{array}{l}\text { Waste } \\
\text { Water }\end{array}$ \\
\hline Phase & Solid & Liquid & Vapour & Liquid & Liquid & Liquid & Liquid \\
\hline Temperature, ${ }^{\circ} \mathrm{C}$ & 25 & 20 & 120 & 50 & 30 & 25 & 25 \\
\hline Pressure, bar & 1 & 1 & 2 & 1 & 1 & 0.2 & 1 \\
\hline TAGs, kg/h & 1769.8 & 0 & 0 & 897.6 & 872.2 & 0 & 0 \\
\hline DAGs, $\mathrm{kg} / \mathrm{h}$ & 20 & 0 & 0 & 9.4 & 10.6 & 0 & 0 \\
\hline MAGs, $\mathrm{kg} / \mathrm{h}$ & 1.6 & 0 & 0 & 0.8 & 0.8 & 0 & 0 \\
\hline FAs, $\mathrm{kg} / \mathrm{h}$ & 200.1 & 0 & 0 & 28.2 & 171.9 & 0 & 0 \\
\hline Minors $^{\mathrm{a}}, \mathrm{kg} / \mathrm{h}$ & 8.5 & 0 & 0 & 4 & 4.5 & 0 & 0 \\
\hline Acetone, $\mathrm{kg} / \mathrm{h}$ & 0 & 9.3 & 0 & 0 & 0.1 & 9.2 & 0.2 \\
\hline Water, $\mathrm{kg} / \mathrm{h}$ & 0 & 0 & 13.2 & 2.6 & 1.7 & 9.2 & 9.2 \\
\hline
\end{tabular}




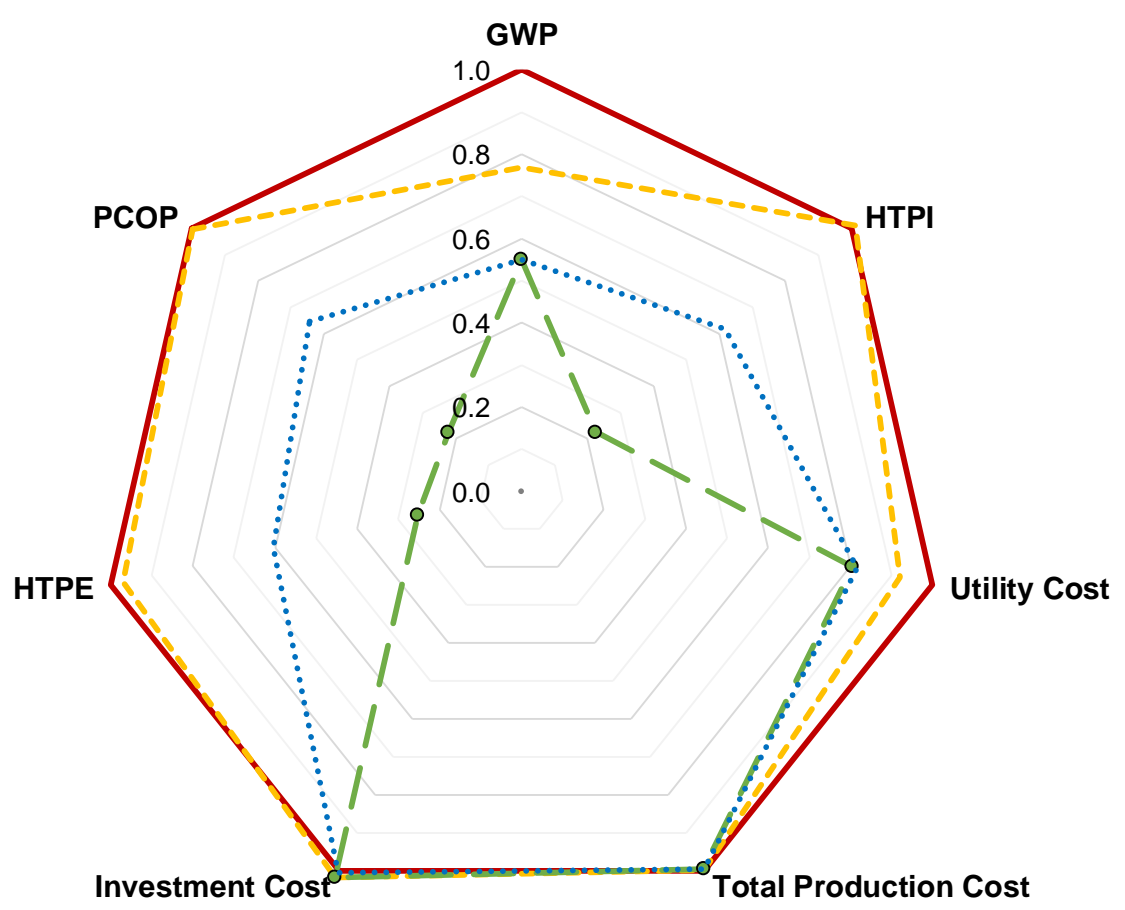

Figure 8. Comparison of proposed process alternatives with respect to the Base case scenario for different economic and environmental impact indicators. Base case ( - ), Alternative 1 ( - - - ), Alternative $2(--)$, Alternative $3(\cdots)$.

In the presented analysis of the shea butter solvent fractionation process throughout the Base case scenario and three process alternatives, potential improvements that can be brought to the industrial process are proposed. The improvements are focused around heat integration of some of the process streams and can lead to significant cuts in utility costs (e.g. up to $28 \%$ ). This could be valuable at the industrial level, since the shea stearin market price is highly dependent on the cocoa butter price, and during low price periods the process can keep good profitability. Moreover, the improvements in energy consumption have a positive impact on the process sustainability, with a reduction in GWP indicator up to $43 \%$. Further improvements in process sustainability can be achieved if renewable resources are used for providing the process utilities (e.g. biofuels, renewable electricity). 


\section{CONCLUSIONS}

In the present work, a systematic and generic method for lipid processing is described and exemplified through a case study for shea butter acetone fractionation process. The method involves four steps dedicated to data collection and problem definition, modelling and simulation, process analysis and process improvement, and which cover stage two and three of the synthesisdesign-innovation framework ${ }^{20}$. The energy consumption for the solvent recovery, one of the main drawbacks of solvent fractionation processes, is identified in the process analysis step as the main area for improvement. The problem is addressed in step four by applying heat integration concepts and by implementing a side draw column in three process alternatives solutions. The process analysis of the alternatives indicates Alternative 2 as the best solution (i.e. $855 \mathrm{~kW}$ energy savings) which lead to lower operating cost and improvements in process sustainability (i.e. $40 \%$ lower GWP). The method is suitable to be applied for other lipid fractionation processes, especially the ones involving solvent recovery where significant energy savings can be achieved. Future studies should focus on detailed modelling of the lipid crystallisation process. This could offer a great advantage for the process solvent selection which can be done through a systematic solvent screening approach ${ }^{71}$ and which could lead to a lower oil-solvent ratio, and ultimately to lower process energy requirements and environmental impact, making the solvent fractionation process more sustainable and profitable.

The application of the lipid thermodynamic models for both pure compounds and mixtures throughout the study highlights the importance of the availability of these models, of their ability to describe lipid-based industrial processes and the importance of having these models integrated within a database which is easily connected to different computer-aided tools. All these are reflected in the application of the models for the first time to shea butter solvent fractionation for 
which important improvements in process performance are achieved. The current available thermodynamic models, especially the ones describing the phase equilibria, can be further finetuned and expanded to include other lipid systems (once more experimental data are available) to expand the utilisation of the method and thermodynamic models to other lipid-based processes, such as oleochemicals production which involve more complex compounds and mixtures (e.g. fatty dicarboxylic acids, fatty amines, etc.).

\section{ASSOCIATED CONTENT}

\section{Supporting Information}

The Supporting Information file contains following additional information: pure component property models used, Original UNIFAC binary interaction parameters matrix used within process simulations, detailed mass balance for Base case scenario, energy balance for crystallizer, outlet streams for Base case and Alternative 3, SLE binary data for shea butter compounds, acetonewater VLE prediction with UNIFAC and NRTL. This information is available free of charge via the Internet at http://pubs.acs.org/

\section{AUTHOR INFORMATION}

\section{Corresponding Author}

*E-mail: gk@kt.dtu.dk

\section{ORCHID}

Olivia A. Perederic: 0000-0002-2751-113X

Seyed Soheil Mansouri: 0000-0002-0924-4947

John M. Woodley: 0000-0002-7976-2483

Georgios M. Kontogeorgis: 0000-0002-7128-1511

\section{ABBREVIATIONS}


ARD Average Relative Deviation; ATP Aquatic Toxicity Potential; CBE Cocoa Butter Equivalent; CW Cooling Water; DAG Diacylglycerol; FA Fatty Acid; GWP Global Warming Potential; HEN Heat Exchanger Network; HTPE Human Toxicity Potential by Exposure; HTPI Human Toxicity Potential by Ingestion; LP Low Pressure steam; MAG Monoacylglycerols; $\mathrm{NH}_{3}$ Ammonia cooling; ODP Ozone Depletion Potential; PCOP Photochemical Oxidation Potential; PFD Process Flowsheet Diagram; PFD Process Flowsheet Diagram; POP 1,3-dipalmito-2-olein triglyceride; PPO 1,2-dipalmito-3-olein triglyceride; PSE Process Systems Engineering; Q Quality factor of VLE datasets; ROR Rate of Return; T* Shifted temperature; TAG Triacylglycerol; TS Supply temperature; TT Target Temperature.

\section{REFERENCES}

(1) Cheng, M. H.; Dien, B. S.; Singh, V. Economics of plant oil recovery: A review. Biocatal. Agric. Biotechnol. 2019, 18, 101056.

(2) Perederic, O. A.; Cunico, L. P.; Kalakul, S.; Sarup, B., Woodley, J. M.; Kontogeorgis, G. M.; Gani, R. Systematic identification method for data analysis and phase equilibria modelling for lipids systems. J. Chem. Thermodyn. 2018,121, 153-169.

(3) Martinho, A.; Matos, H. A.; Gani, R.; Sarup, B.; Youngreen, W. Modelling and simulation of vegetable oil processes. Food Bioprod. Process. 2008, 86, 87-95.

(4) Díaz-Tovar, C. A.; Gani, R.; Sarup, B. Lipid technology: Property prediction and process design/analysis in the edible oil and biodiesel industries. Fluid Phase Equilib. 2011, 302, 284-293.

(5) Landucci, G.; Pannocchia, G.; Pelagagge, L.; Nicolella, C. Analysis and simulation of an industrial vegetable oil refining process. J. Food Eng. 2013, 116, 840-851. 
(6) Stiefel, S.; Dassori, G. Simulation of Biodiesel Production through Transesterification of Vegetable Oils. Ind. Eng. Chem. Res. 2009, 48, 1068-1071.

(7) Sotoft, L. F.; Rong, B.-G.; Christensen, K. V.; Norddahl, B. Process simulation and economical evaluation of enzymatic biodiesel production plant. Bioresour. Technol. 2010, 101, 5266-74.

(8) Aboelazayem, O.; Gadalla, M.; Saha, B. Design and simulation of an integrated process for biodiesel production from waste cooking oil using supercritical methanolysis. Energy 2018, 161, 299-307.

(9) Gani, R.; O’Connell, J. P. Role of Properties and their Models in Process and Product Design. In Computer Aided Property Estimation for Process and Product Design; Kontogeorgis, G.M., Gani, R.; Eds.; Elsevier B.V.: Amsterdam, 2004, 27-41.

(10) Damaceno, D. S.; Perederic, O. A.; Ceriani, R.; Kontogeorgis, G. M.; Gani, R. Improvement of predictive tools for vapor-liquid equilibrium based on group contribution methods applied to lipid technology. Fluid Phase Equilib. 2018b,470, 249-258.

(11) Cunico, L. P.; Hukkerikar, A. S.; Ceriani, R.; Sarup, B.; Gani, R. Molecular structure-based methods of property prediction in application to lipids: A review and refinement. Fluid Phase Equilib. 2013, 357, 2-18.

(12) Ceriani, R.; Gani, R.; Liu, Y. A. Prediction of vapor pressure and heats of vaporization of edible oil/fat compounds by group contribution. Fluid Phase Equilib. 2013, 337, 53-59.

(13) Smith, K.W. Confectionery Fats. In Cocoa Butter and Related Compounds; Garti, N., Widlak, N.R.; Eds.; AOCS Press: Urbana, 2012, 475-495. 
(14) Lovett, P.N. Shea butter: Properties and processing for use in food. In Specialty Oils and Fats in Food and Nutrition: Properties, Processing and Applications; Talbot G.; Ed.; Elsevier Ltd.: Amsterdam, 2015, 125-157.

(15) Kellens, M.; Gibon, V.; Hendrix, M.; De Greyt, W. Palm oil fractionation. Eur. J. Lipid Sci. Technol. 2007, 109, 336-349.

(16) Dijkstra, A.J. Modification Processes and Food Uses. In The Lipid Handbook; Gunstone, F.D., Harwood, J.L., Dijkstra, A.J.; Eds.; CRC Press: Boca Raton, 2007, 263-353.

(17) Timms, R.E. Processing methods. In: Confectionery Fats Handbook; Timms R.; Ed.; Woodhead Publishing: Cambridge, 2012, 105-142.

(18) Hashimoto, S.; Nezu, T.; Arakawa, H.; Ito, T.; Maruzeni, S. Preparation of sharp-melting hard palm midfraction and its use as hard butter in chocolate. JAOCS, J. Am. Oil Chem. Soc. 2001, $78,455-460$.

(19) Salas, J. J.; Bootello, M. A.; Martínez-Force, E.; Garcés, R. Production of stearate-rich butters by solvent fractionation of high stearic-high oleic sunflower oil. Food Chem. 2011, 124, $450-458$.

(20) Bertran, M.-O.; Frauzem, R.; Sanchez-Arcilla, A.-S.; Zhang, L.; Woodley, J. M.; Gani, R. A generic methodology for processing route synthesis and design based on superstructure optimization. Comput. Chem. Eng. 2017, 106, 892-910.

(21) Vooradi, R.; Bertran, M.-O.; Frauzem, R.; Anne, S.B.; Gani, R. Sustainable chemical processing and energy-carbon dioxide management: Review of challenges and opportunities. Chem Eng Res Des. 2018, 131, 440-464. 
(22) Garg, N.; Woodley, J. M.; Gani, R.; Kontogeorgis, G.M. Sustainable solutions by integrating process synthesis-intensification. Comput Chem Eng. 2019, 26, 499-519.

(23) Kongpanna, P.; Pavarajarn, V.; Gani, R.; Assabumrungrat, S. Techno-economic evaluation of different $\mathrm{CO}_{2}$-based processes for dimethyl carbonate production. Chem Eng Res Des. 2015, 93, 496-510.

(24) Handani, Z. B.; Quaglia, A.; Gani, R. Synthesis and Design of Integrated Process and Water Networks; In Computer Aided Chemical Engineering Vol 37; Gernaey, K. V.; Huusom, J. K.; Gani, R.; Eds.; Elsevier B.V.: Amsterdam, 2015, 875-880.

(25) Bertran, M.-O.; Orsi, A.; Manenti, F.; Woodley, J. M.; Gani, R. Synthesis of Sustainable Biofuel Production Processes: A Generic Methodology for Superstructure Optimization and Data Management. In: Kopanos GM, Liu P, Georgiadis MC, eds. Advances in Energy Systems Engineering. Cham, Swizerland: Springer; 2016, 651-681.

(26) Perederic, O. A.; Appel, S.; Sarup, B.; Woodley, J. M.; Kontogeorgis, G. M.; Gani, R. Design and Analysis of Edible Oil Processes Containing Lipids. Comput. Aided Chem. Eng. 2018a, 43, 737-742.

(27) Seider, W. D.; Lewin, D. R.; Seader, J. D.; Widagdo, S.; Gani, R.; Ng, K. M. Product and process design principles: synthesis, analysis, and evaluation, Fourth ed. Wiley, 2016.

(28) Peters, M. S.; Timmerhaus, K. D.; West, R. E. Plant Design and Economics for Chemical Engineers. 5th ed; McGraw-Hill Education: Boston, 2004. 
(29) Kalakul, S.; Malakul, P.; Siemanond, K.; Gani, R. Integration of life cycle assessment software with tools for economic and sustainability analyses and process simulation for sustainable process design. J Clean Prod. 2014, 71, 98-109.

(30) de Bruijn, H.; van Duin, R.; Huijbregts, M. A. J. Handbook on Life Cycle Assessment. Operational Guide to the ISO Standards; Kluwer Academic Publishers: Dordrecht; 2002.

(31) National Renewable Energy Laboratory. US EPA LCI Database. https://www.nrel.gov/lci/about.html.

(32) Kang, K. K.; Jeon, H.; Kim, I. H.; Kim, B. H. Cocoa butter equivalents prepared by blending fractionated palm stearin and shea stearin. Food Sci. Biotechnol. 2013, 22, 347-352.

(33) AVEVA Group plc. PRO/II TM Process Engineering User Guide. Cambridge, UK; 2018.

(34) Perederic, O. A. Systematic computer aided methods and tools for lipid process technology. Ph.D. Thesis, Technical University of Denmark, December 2018.

(35) Kang, J. W.; Abildskov, J.; Gani, R.; Cobas, J. Estimation of mixture properties from firstand second-order group contributions with the UNIFAC model. Ind. Eng. Chem. Res. 2002, 41, $3260-3273$.

(36) Kang, J. W.; Diky, V.; Chirico, R. D.; Magee, J. W.; Muzny, C. D.; Abdulagatov, I.; Kazakov, A. F.; Frenkel, M. Quality Assessment Algorithm for Vapor-Liquid Equilibrium Data. J. Chem. Eng. Data 2010, 55, 3631-3640.

(37) Huang, R.; Gu, Y.; Hou, Y. VLE of Acetone-Water-Isobutyraldehyde System. Chem. Eng. 1984, 4, 26-29. 
(38) Verhoeye, L. A.; Deschepper, H. The vapour-liquid equilibria of the binary, ternary and quaternary systems formed by acetone, methanol, propan-2-ol, and water. J. Applid Chem. Biotechnol. 1973, 23, 607.

(39) Al-Shhaf, T. A. Vapor-Liquid Equilibrium of the Acetone-Water-Salt System. J. Chem. Eng. Data 1993, 38, 522-526.

(40) Eduljee, G. H.; Boyes, A. P. Excess Gibbs Energy for eight oleic acid+solvent and trioleinsolvent mixtures at 318.15K. J Food Process Eng 1981, 26, 55-57.

(41) Diky, V.; Chirico, R. D.; Muzny, C. D.; Kazakov, A. F.; Kroenlein, K.; Magee, J. W.; Abdulagatov, I.; Kang, J. W.; Frenkel, M. ThermoData Engine (TDE) software implementation of the dynamic data evaluation concept. 7. Ternary mixtures. J. Chem. Inf. Model. 2012, 52, 260-76.

(42) Zhang, Z.; Ma, X.; Huang, H.; Wang, Y. Shea olein based specialty fats: Preparation, characterization and potential application. LWT - Food Sci Technol. 2017, 86, 492-500.

(43) Ray, J.; Smith, K. W.; Bhaggan, K.; Nagy, Z. K.; Stapley, A. G. F. Crystallization and polymorphic behavior of shea stearin and the effect of removal of polar components. Eur. J. Lipid Sci. Technol. 2013, 115, 1094-1106.

(44) Badu, M.; Awudza, J.; Budd, P.M.; Yeates, S. Determination of Physical Properties and Crystallization Kinetics of Oil from Allanblackia Seeds and Shea Nuts Under Different Thermal Conditions. Eur J Lipid Sci Technol. 2018, 120(3), 1-9.

(45) Wesdorp, L. H.; Van Meeteren, J. A.; De Jong, S.; Giessen, R. V. D.; Overbosch, P.; Grootscholten, P. A. M.; Struik, M.; Royers, E.; Don, A.; de Loos, Th.; Peters, C.; Gandasasmita, 
I. Liquid-multiple solid phase equilibria in fats: Theory and experiments. In: Fat Crystal Networks. 1st ed.; Marangoni A. G.; Ed.; CRC Press: Boca Raton; 2004, 481-709.

(46) Rocha, S. A.; Guirardello, R. An approach to calculate solid-liquid phase equilibrium for binary mixtures. Fluid Phase Equilib. 2009, 281(1), 12-21.

(47) Teles M.; Le Roux, G. A. C.; Gerbaud V. Phase Equilibrium and Optimization Tools: Application for Enhanced Structured Lipids for Foods. J Am Oil Chem Soc, 2011, 223-233.

(48) Foubert, I.; Vanrolleghem, P. A. Modelling of the crystallization kinetics of fats. Trends Food Sci. Tech. 2003, 14, 79-92.

(49) Rousset, P. Modeling Crystallization Kinetics of Triacylglycerols. In Physical Properties of Lipids; Marangoni A.G.; Narine S. S.; Eds.; CRC Press: Boca Raton; 2002.

(50) Avrami, M. Kinetics of phase change. I: General theory. J Chem Phys. 1939, 7(12), 11031112.

(51) Avrami, M. Kinetics of phase change. II Transformation-time relations for random distribution of nuclei. J Chem Phys. 1940, 8(2), 212-224.

(52) Erofeev, B.V. Reactivity of Solids. In Proc. 4th. Int. Symp. on Reactivity of Solids, De Boer J. H., Ed.; Elsevier B.V.: Amsterdam; 1960, 273-282.

(53) Ng, W. Thermal decomposition in the solid state. Aust J Chem. 1975, 28(6), 1169-1178.

(54) Zwietering, M. H.; Jongenburger, I.; Rombouts, F. M.; van 't Riet, K. Modeling of the Bacterial Growth Curve. Appl Environ Microbiol. 1990, 56(6), 1875-1881. 
(55) Kloek, W.; Walstra, P.; van Vliet, T. Crystallization Kinetics of Fully Hydrogenated Palm Oil in Sunflower Oil Mixtures. JAOCS, J Am Oil Chem Soc. 2000, 77(4), 389-398.

(56) Foubert, I.; Vanrolleghem, P. A.; Vanhoutte, B.; Dewettinck, K. Dynamic mathematical model of the crystallization kinetics of fats. Food Res Int. 2002, 35, 945-956.

(57) Schall, J. M.; Mandur, J. S.; Braatz, R. D.; Myerson, A. S. Nucleation and Growth Kinetics for Combined Cooling and Antisolvent Crystallization in a Mixed-Suspension, Mixed-Product Removal System: Estimating Solvent Dependency. Cryst. Growth Des. 2018, 18, 1560-1570.

(58) Hjorth, J. L.; Miller, R. L.; Woodley, J. M; Kiil, S. Thermodynamic Modeling of Multiphase Solid - Liquid Equilibria in Industrial-Grade Oils and Fats. J Am Oil Chem Soc 2015, 92, $17-28$

(59) Hjorth, J. L.; Miller, R. L.; Woodley, J. M.; Kiil S. Kinetic modeling of multi-component crystallization of industrial-grade oils and fats. Eur J Lipid Sci Technol. 2015, 117(7), 1066-1078.

(60) Bek-Pedersen, E.; Gani, R. Design and synthesis of distillation systems using a drivingforce-based approach. Chem Eng Process. 2004, 43, 251-262.

(61) Lopez-Arenas, T.; Mansouri, S. S.; Sales-Cruz, M.; Gani, R.; Pérez-Cisneros, E. S. A Gibbs energy-driving force method for the optimal design of non-reactive and reactive distillation columns. Comput Chem Eng. 2019, 128, 53-68.

(62) Biegler, L. T.; Grossmann, I. E.; Westerberg, A.W. Systematic Methods of Chemical Process Design. Prentice Hall: New Jersey; 1997.

(63) Plant Cost Index, Chemical Engineering. www.chemengonline.com/ Assets/File/CEPCI_2002.pdf. Published 2018. Accessed February 15, 2019. 
(64) Harahap, F.; Silveira, S.; Khatiwada, D. Cost competitiveness of palm oil biodiesel production in Indonesia. Energy. 2019, 170, 62-72.

(65) Budžaki, S.; Miljić, G.; Sundaram, S.; Tišma, M.; Hessel, V. Cost analysis of enzymatic biodiesel production in small-scaled packed-bed reactors. Appl Energy. 2018, 210, 268-278.

(66) CBI Market Intellingence. CBI Product Factsheet: Shea Butter in Europe.; 2015.

(67) Chembid. Online search engine for chemicals and services. https://www.chembid.com/. Published 2017. Accessed February 27, 2019

(68) Boulamanti, A.; Moya, J. A. Production costs of the chemical industry in the EU and other countries: Ammonia, methanol and light olefins. Renew Sustain Energy Rev. 2017, 68, 1205-1212.

(69) Klemeš, J. J.; Varbanov, P. S.; Wan Alwi, S. R.; Manan, Z.A. Process Integration and Intesnification. Saving Energy, Water and Resources. Berlin: Walter de Gruyter GmbH; 2014.

(70) Kemp I. C. Pinch Analysis and Process Integration: A User Guide on Process Integration for the Efficient Use of Energy 2nd ed., Elsevier B.V.: Amsterdam, 2007.

(71) Papadakis, E.; Tula, A. K.;, Gani R. Solvent selection methodology for pharmaceutical processes: Solvent swap. Chem Eng Res Des 2016, 115, 443-61. 
2

3

4

5

6

7

8

9

10

11

12

13

14

15

16

17

18

19

20

21

22

23

24

25

26

27

28

29

30

31

32

33

34

35

36

37

38

39

40

41

42

43

44

45

46

47

48

49

50

51

52

53

54

55

56

57

58

59

60

\section{Abstract TOC Graphic}

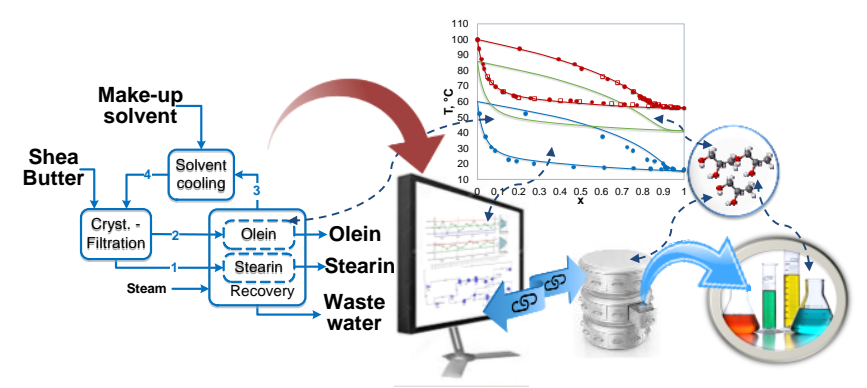

KEYWORDS: lipid, process design, shea butter, solvent fractionation, process heat integration, process modelling and simulation, lipid processing 